IZA DP No. 10095

The Long-lasting Shadow of the Allied Occupation of Austria on its Spatial Equilibrium

Christoph Eder

Martin Halla

July 2016 


\title{
The Long-lasting Shadow of the Allied Occupation of Austria on its Spatial Equilibrium
}

\author{
Christoph Eder \\ University of Innsbruck
}

\author{
Martin Halla \\ University of Innsbruck \\ and IZA
}

\section{Discussion Paper No. 10095 \\ July 2016}

\author{
IZA \\ P.O. Box 7240 \\ 53072 Bonn \\ Germany \\ Phone: +49-228-3894-0 \\ Fax: +49-228-3894-180 \\ E-mail: iza@iza.org
}

Any opinions expressed here are those of the author(s) and not those of IZA. Research published in this series may include views on policy, but the institute itself takes no institutional policy positions. The IZA research network is committed to the IZA Guiding Principles of Research Integrity.

The Institute for the Study of Labor (IZA) in Bonn is a local and virtual international research center and a place of communication between science, politics and business. IZA is an independent nonprofit organization supported by Deutsche Post Foundation. The center is associated with the University of Bonn and offers a stimulating research environment through its international network, workshops and conferences, data service, project support, research visits and doctoral program. IZA engages in (i) original and internationally competitive research in all fields of labor economics, (ii) development of policy concepts, and (iii) dissemination of research results and concepts to the interested public.

IZA Discussion Papers often represent preliminary work and are circulated to encourage discussion. Citation of such a paper should account for its provisional character. A revised version may be available directly from the author. 


\section{ABSTRACT}

\section{The Long-lasting Shadow of the Allied Occupation of Austria on its Spatial Equilibrium*}

As a consequence of World War II, Austria was divided into four different occupation zones for 10 years. Before tight travel restrictions came into place, about 11 percent of the population residing in the Soviet zone moved across the demarcation line. We exploit this large internal migration shock to further our understanding of why economic activity is distributed unevenly across space. Our analysis shows that the distorted population distribution across locations has fully persisted until today (60 years after the demarcation line become obsolete). An analysis of more direct measures of economic activity shows an even higher concentration in the former non-Soviet zone. This gap in economic activity is growing over time, mainly due to commuting streams out of the former Soviet zone. This shows that a transitory shock is capable of shifting an economy to a new spatial equilibrium, which provides strong evidence for the importance of increasing returns to scale in explaining the spatial distribution of economic activity.

JEL Classification: R11, R12, R23, J61, N44, N94

Keywords: spatial equilibrium, agglomeration effects, population shock, World War II, Austria

Corresponding author:

Christoph Eder

Department of Public Finance

University of Innsbruck

Universitätsstraße 15/4

6020 Innsbruck

Austria

E-mail: christoph.eder@uibk.ac.at

\footnotetext{
${ }^{*}$ For helpful discussion and comments, we would like to thank Christopher Kah, Michael Pfaffermayr, participants of the $10^{\text {th }}$ eeecon workshop at the University of Innsbruck, the ISW-Workshop at the University of Innsbruck, BeNA in Berlin, and the NOeG in Klagenfurt. The usual disclaimer applies.
} 


\section{Introduction}

A long-standing question in economic geography is why economic activity is so highly unevenly distributed across space. While there is broad consensus that densely populated areas offer higher levels of productivity, the source of the productivity gain is less clear. The economic literature offers two - possibly not mutually exclusive - explanations for this uneven distribution. The locational fundamentals theory considers geographic features (firstnature characteristics) as the driving force behind the spatial distribution (see, e.g., Head and Mayer, 2004). Accordingly, economic activity is concentrated in areas with attractive natural endowments, such as access to a river or large plain. Another family of theories (henceforth, scale economy models) stresses the importance of the local interaction of economic agents (second-nature characteristics). The seminal papers of Henderson (1974); Krugman (1991), and the subsequent literature demonstrate how agglomeration and dispersion forces (e.g., internal increasing returns to scale and trade costs) determine the spatial distribution of economic activity. Put differently, individuals may cluster in areas that are innately more productive, or density itself may enhance productivity because of agglomeration economies. ${ }^{1}$

Empirically, it is typically difficult to disentangle these two effects, since the first-nature characteristics are persistent and may promote agglomeration effects. To break the link between natural advantage and scale, we suggest exploiting a unique policy episode in Austria.

In the immediate aftermath of World War II (WWII), Austria was divided into four occupation zones, which were allotted to the United States of America (US), the Union of Soviet Socialist Republics (USSR or Soviet), the United Kingdom of Great Britain and Northern Ireland (UK), and the French Republic (French). Before tight travel restrictions become effective, about 11 percent of the population residing in the Soviet zone escaped, fearing abuse and mistreatment by the Soviet Army. This internal migration response constitutes a large exogenous shock to scale - it moved population and economic activity across space — while leaving first-nature characteristics unaltered. Despite this partition, during Austria's occupation, it was treated as one political unit, that is, a state to be. In 1955, the occupation regime ended and residents were completely free to move again.

The two theories outlined above provide different predictions for the adjustment of the spatial distribution in response to the population shock for the period after 1955 (i.e., the year when the former demarcation line became obsolete). The locational fundamentals theory predicts a reversion to the initial distribution, since natural advantages of particular locations reassert themselves, and push the economy back to the unique spatial equilibrium.

\footnotetext{
${ }^{1}$ Another related theoretical framework is the random growth theory. According to this purely mathematical framework, with no optimization or equilibrium concept, city growth follows a random walk and, in the steady state, the city size distribution obeys Zipf's Law (Gabaix, 1999).
} 
By contrast, scale economy models generally allow for multiple equilibria. If the shock is sufficiently large, it switches the economy from one equilibrium to another. Thus, the internal migration shock may have permanent effects and shifts the spatial equilibrium.

To inform our empirical analysis we provide a simple spatial equilibrium model of the labor market. Following Moretti (2011), we describe a closed full-employment economy with a fixed number of workers. Workers are mobile and locate where indirect utility is maximized. Workers have idiosyncratic preferences over different locations, which also offer certain local amenities. Firms potentially experience agglomeration economies and face adjustment frictions. The most important conclusion we derive from this simple model for our empirical analysis is that a temporary amenity shock, such as the Allied occupation, can shift the spatial equilibrium only if both agglomeration effects and some type of frictions are present.

In our empirical analysis, we focus closely on cleanly disentangling the causal effect of the internal migration shock from unobserved confounding factors. We exploit the spatial discontinuity created by the demarcation line within a regression-discontinuity design, as well as pre-WWII data to cancel out pre-treatment differences between the Soviet and non-Soviet zones, in the spirit of a difference-in-differences (DiD) estimator. This combination of quasiexperimental methods fully confirms the picture painted by simple descriptive statistics and hence, supports the assumption that the location of the demarcation line was exogenous. First, we examine the effect on the spatial distribution of the population based on Austrian census data sources, covering the period from 1869 until today. This outcome measure is the standard proxy for economic activity in the existing literature so far. Second, we improve on the existing evidence by employing more precise and informative measurements of economic activity. For more recent decades, we obtain detailed information on local employment, commuting streams, sectoral composition, and housing stock. This type of data allows us to distinguish between the places of residence and work in the analysis of spatial equilibrium.

We find evidence that fully corroborates the importance of economies of scale and points to the presence of some mobility frictions. First, the distorted distribution of population in space has fully persisted until today (i.e., almost 7 decades later). Second, the effect on the spatial distribution of economic activity is growing over time. The increase in the density of population led to a disproportionately high concentration of economic activity. That means, the spatial distribution of economic activity became even more concentrated than the distribution of the residing population. Based on detailed information on commuting streams, we show that the dominant commuting stream is from the former Soviet to the non-Soviet zone. The existing employment in the Soviet zone was characterized by a slower transition to manufacturing, but a faster growing dominance of services. The housing stock 
quickly responded to the distorted population distribution and has reached a stable difference by 1971. Since then there are 5 percent more houses per capita in the former Soviet zone. We conclude that the internal migration shock was large enough to switch the economy to a new spatial equilibrium. Robustness tests and a placebo strategy fully support our causal interpretation.

The existing empirical literature is relatively sparse and provides conflicting evidence. Existing empirical papers obtain exogenous variations in scale, while holding natural advantages constant, from two types of natural experiments. First, a number of papers use wartime bombing and, second, one paper exploits spatial restrictions in migration. Davis and Weinstein (2002) use the Allied bombing of Japanese cities in WWII as a shock to relative city sizes. They find that after 15 years, most cities returned to their relative positions in the distribution of city sizes. In a follow-up paper, they examine more direct measures of economic activity, and show that Japanese cities also regained their pre-existing industrial output and composition (Davis and Weinstein, 2008). These findings are in line with the prediction of the locational fundamentals theory. Similarly, Brakman et al. (2004) find that the populations of West German cities recovered relatively rapidly from the WWII bombing, and Miguel and Roland (2011) find little evidence of permanent effects from the large-scale bombing of Vietnam on population density or measures of economic activity (poverty and consumption). ${ }^{2}$ The paper most closely related to ours is Schumann (2014), who uses spatial restrictions in the resettlement of German expellees after WWII as an exogenous population shock to parts of West Germany. He finds that 20 years later, more than 80 percent of the initial difference in population is in place. This evidence contradicts the locational fundamentals theory, but is consistent with theories of multiple equilibria based on economies of scale. Intriguingly, Schumann (2014) finds no evidence that the population shock had lasting consequences on more direct measures of economic activity. This in stark contrast to our result: we find that the Allied occupation shock initially had an equally large effect on the spatial distribution of the population and economic activity, with the latter growing sharply over time.

We are aware of only one paper that examines credibly exogenous variation in a natural advantage, while holding scale constant. Bleakley and Lin (2012) show that US cities with a historical natural advantage due to a geomorphological feature grew at an even higher rate after changes in technology made this feature obsolete, compared to cities whose firstnature characteristics have not changed. ${ }^{3}$ This finding is clear evidence of the importance of

\footnotetext{
${ }^{2}$ By contrast, Bosker et al. (2007) find evidence for multiple equilibria in German city growth, and Bosker et al. (2008) conclude that West German city size distribution was permanently affected by the WWII bombing.

${ }^{3}$ In particular, they examine US cities, which historically served as portage sites due to their location along
} 
increasing returns to scale.

The rest of this paper proceeds as follows. Section 2 reviews the historical background of the Allied occupation of Austria after WWII, the escape from the Soviet zone, and potential differences in wartime destruction and reconstruction efforts across zones. Section 3 presents our simple spatial equilibrium model and derives theoretical predictions for the effect of the Allied occupation on the post-WWII spatial equilibrium of Austria. Section 4 discusses the data and its construction, presents some descriptive statistics, and explains our identification strategy in more detail. Section 5 summarizes our main estimation results and provides falsification and robustness tests. Section 6 concludes.

\section{The Allied Occupation of Austria after WWII}

Already in October 1943, the major Allies (UK, US, and USSR) started to coordinate planning for the post-war period. Most importantly for Austria, the foreign secretaries agreed in the so-called Moscow Declaration that Austria had been the first victim of the aggressive foreign policy of Nazi Germany. ${ }^{4}$ They regarded 'the annexation imposed upon Austria by Germany's penetration of March 15, 1938, as null and void' and called for the re-establishment of a free and independent Austria after the victory over Nazi Germany.

The establishment of occupation zones was referred to the newly established European Advisory Commission (EAC), which began its planning in January 1944. The purpose of this occupation, as formulated in the final version of the so-called Agreement on Control Machinery in Austria, was to achieve the separation of Austria from Germany; to secure the establishment of a central Austrian administrative machine to prepare the way for free elections; and to provide a provisional administration for Austria. The major Allies started to submit their zoning proposals unilaterally to the EAC as early as January 1944. This initiated long and tough negotiations. In January 1945, France joined and made her bid for a zone in Austria (Erickson, 1950). An agreement was not reached until 3 months after Austria had fallen to the Allies on July 9, 1945. Immediately thereafter, a zone swap took place, which altered the former agreement substantially (Eisterer, 2009). ${ }^{5}$ Parts of Upper

the so-called fall line, where rivers tend to have rapids and falls. Because of these features, riverboats typically could not travel any farther inland without portaging (i.e., hauling goods and boats over land). Portage sites were focal points for commercial activity and entrepot trade. Their empirical analysis shows that after 1850, when the use of water transport and portage declined, due to the construction of canals/railroads, the population at portage sites grew at a comparably high rate.

${ }^{4}$ The validity of this so-called victim theory has been questioned ever since. Historians, politicians, and the public in Austria have debated whether the Anschluss was voluntary or forced. Today there is absolute consensus that the Anschluss found broad support in the Austrian population at the time and that a large proportion of Austrians were collaborators and co-perpetrators.

${ }^{5}$ Among others, the UK took over most of Styria from the Soviets and the Americans, the Soviets replaced 
Austria were only temporarily under non-Soviet occupation, while parts of Styria were under Soviet occupation only for a couple of months. A summary of the final zone agreements was released simultaneously by the four governments on August 8, 1945 (Erickson, 1950). Figure 1 displays the finals borders, which we use for our analysis. ${ }^{6}$ The USSR obtained the northeast sector, the US the northwest sector, France the southwest tip, and the UK the southeast sector. Vienna, the capital, was similarly subdivided but the central district was administered jointly by the Allied Control Council.

The occupation lasted much longer than initially intended, since state treaty negotiations were obstructed by the emerging Cold War (Ferring, 1968). The negotiations started in 1947, were in a state of suspension from mid-1950 to 1953, were resumed in 1954, and finalized in 1955. On May 15, 1955 the Austrian State Treaty was signed among the Allied occupying forces and re-established a free, sovereign, and democratic Austria by July 27, 1955. As a result of this treaty, the Allies left Austrian territory on October 25, 1955.

\subsection{Travel Restrictions and Migration Response}

Soviet troops crossed the former Austrian border in the state of Burgenland on March 29, 1945. Due to Nazi propaganda demonizing communists, as well as factual reports on misconduct of the Soviet Army in Hungary, the Austrian population was terrified by the arriving liberators. Sadly, the seeking of revenge and craving for booty indeed led to assaults on the local population (Petrov, 2009). The already poor reputation of the Soviet soldiers was further ruined, in particular, by the vast amount of sexual violence against women. By contrast, the reputation of the troops of the Western Allies, who entered the Austrian border in the West about 1 month later, was much better. ${ }^{7}$ In addition, residents of the designated Soviet occupation zone were anxious about unclear political development under a communist occupation. As a result, between April and June 1945, many of them escaped westwards to the area of the expected occupation zones of the Western Allies. In this subsection, we describe the timing of intra-Austrian travel restrictions. Furthermore, we discuss the estimated size and composition of this internal migration response.

Travel restrictions The time period from the invasion of the Soviet troops at the end of

the Americans in the North of Upper Austria in the so-called Mühlviertel, and France received Tyrol, which was initially assigned to the US.

${ }^{6}$ Our analysis, based on the final borders, provides a conservative estimate for the regions affected by the last-minute zone swaps, to the extent that exposure to other occupation forces before the zone swap had an effect on the outcomes of interest.

${ }^{7}$ Ex post, this assessment proved to be correct; the numbers of registered crimes by foreign troops during the occupation period was much higher in the Soviet zone. Evidence for sexual violence against women is based on oral history (Stelzl-Marx, 2012, page 411f) and corroborated by a sharp increase in the incidence of sexually transmitted disease among Austrian women compared to Austrian men in 1945 (Eppel, 1995 ). 
March 1945 until the first agreement on the occupation zones in early July 1945 was marked by chaos. Everything depended on the military administration that had been installed. Conditions differed not only among the designated occupation zones, but also with respect to the individual division and particular local commander (Eisterer, 2009). The different military commanders shared an interest in ensuring the security of their troops as well as in maintaining law and order. In line with this, several oral historic sources report the presence of curfews and strict travel restrictions. ${ }^{8}$ Thus, it seems that it is not possible to reconstruct at which time in which region people had the opportunity to escape the designated Soviet zone. This escape was further complicated by the unclear position of the demarcation line, and the last-minute zone swaps.

The period after July 1945 can be characterized by two regimes defined by the so-called first and second control agreements. Under the first control agreement, from July 4, 1945, the occupying power had full control and travelling across occupation zones was restricted heavily. The period after the second control agreement, from June 28, 1946, was characterized as a gradual emancipation of the Austrian government, which took back more and more powers from the occupiers. Already, starting from October 22, 1945, it was possible for Austrian citizens to travel across occupation zones. A so-called inter-Allied identity card was needed. However, the constant checking of the movement of people and goods across lines of demarcation ceased only on June $9,1953 .^{9}$

Total migration response Since many people expected better conditions in the nonSoviet zone, in March 1945, they escaped westwards despite the ongoing war. This internal migration is not documented in official figures, but is captured in numerous oral history sources, which describe large streams of refugees in the streets (see, e.g., Mascher-Pichler, 2009). The quantitative extent of the internal migration response (i.e., the shift from the Soviet to non-Soviet zones), to the best of our knowledge, has not been documented so far. This is surprising, since it is clearly visible in simple time-series data.

Figure 2 plots the differential population levels in both regions over time. In Panel (a), we use data from all Austrian municipalities, with the exception of the cities of Vienna and Linz, both of which were occupied by Soviet and non-Soviet forces. In Panel (c), we focus on municipalities bordering the former demarcation line. In both panels, we compare the mean log population levels relative to 1939. In Panels (b) and (d), we plot the respective difference between the two regions. We observe that the population growth path before WWII is quite similar across occupation zones. A striking feature is post-WWII development. Based on the data from the whole of Austria (Panel (b)), between 1939 and 1951, we observe a reduction

\footnotetext{
${ }^{8}$ See, for instance, https://www.stadt-salzburg.at/pdf/stadtchronik_1945_bis_1955.pdf.

${ }^{9}$ Within the occupation zones of the Western Allies, cross-border control ceased as early as 1947.
} 
of almost 15 percent in the population of the Soviet zone. This graph suggests that the difference has grown over time and is about 30 percent today. Panel (d) shows an equivalent graph based on a smaller sample, focusing on municipalities bordering the demarcation line. We expect these graphs to provide a more informative estimate, since municipalities on both sides should be quite comparable. Another advantage of this sample is that we observe population levels already in 1946 and 1948. ${ }^{10}$ Again, we observe a population drop immediately after WWII. In these data, the drop turns out to be sharper and more stable over time. This suggests that about 11 percent of the population residing in the Soviet zone escaped permanently before travel restrictions were put in place. In our empirical analysis below, we investigate this population drop in great detail.

External versus internal migration response In 1945, there was a large influx into Austria of ethnic German refugees (so-called Volksdeutsche) and other displaced people, who had left their homes either voluntarily or by compulsion. The majority of the ethnic German refugees came from neighboring countries, such as Yugoslavia, Czechoslovakia, Romania, and Hungary. From these approximately 540,000 refugees, only 340,000 stayed permanently in Austria (Radspieler, 1955, page 66). For the purpose of our analysis, it is decisive to know in which proportion these refugees settled, or were allowed to settle, in the Soviet and non-Soviet zones. Oral history sources describe that refugees, irrespective of whether they planned to settle in Austria, attempted to reach the designated zone of the Western Allies. The best available source on the refugees' final residence is an official document by the Office of the United States High Commissioner in Austria (reproduced in Radspieler (1955)). These data show that in 1950 and in 1953, about 86\% of the remaining refugees (ignoring those residing in co-occupied Vienna) were in the non-Soviet zone, and the remaining $14 \%$ in the Soviet zone. In other words, even after accounting for the fact that the non-Soviet zone was larger - before the occupation, about 60 percent of the population were residing in areas outside the Soviet zone - a disproportionately high share of refugees settled in the non-Soviet zone. ${ }^{11}$ Thus, we have to assess to what degree the observed rise in the population level in the non-Soviet zone can be attributed to the selective settlement of external refugees.

Table 2 summarizes two simple estimations of the internal migration response. First, we ignore the influx of external refugees (see rows i and ii). This simple calculation based on a comparison of the total Austrian population in 1939 and 1951 conforms to our estimate based on the time series presented in Panels (d) of Figure 2. This suggests that about 11 percent of the native population residing in the Soviet zone migrated to the non-Soviet zone.

\footnotetext{
${ }^{10}$ We discuss these data and their sources in detail below.

${ }^{11}$ There is evidence showing that (former) Nazis were also more likely to settle in the non-Soviet zone (Ochsner and Roesel, 2016).
} 
Second, we provide an alternative estimation, which accounts for the disproportional influx of external refugees to the non-Soviet zone (see rows $\mathrm{i}$ and iii). This estimation shows that about 2.5 percentage points of the migration response are in fact due to external migration and 8.7 percentage points are due to internal migration. While both migration responses are causally related to the Allied occupation, it useful to know for the interpretation of our results presented in Section 5 that the migration response is predominantly due to internal migration.

Composition of the internal migration response For the purpose of our empirical analysis (i.e., for the test of the two competing hypotheses) only the size of the internal migration shock is crucial. However, for a more comprehensive interpretation of our estimation results, it is useful also to know the composition of the internal migration response. Put differently, we would like to establish whether a selected group of individuals left the designated Sovietzone. In the context of agglomeration effects, human capital seems to be the most important dimension. While there is no pre-WWII data on the stock of human capital available, we can examine information on educational attainment provided by the 1971 census. We focus here on individuals born before 1920. This group completed their formal education before WWII. This sample structure guarantees that their human capital investment decisions were not affected by the Allied occupation. Table 3 compares the educational attainment distribution of individuals born before 1920, measured in 1971, residing in 95 neighboring municipalities along the demarcation line (the sample is discussed in more detail in Subsection 4.2). We observe that individuals living in municipalities along the former demarcation line have basically an identical educational attainment on both sides. Clearly, without data on educational attainment measured before 1945, we cannot conclude unambiguously whether migrants were a selected group.

To approximate the educational attainment before the occupation, district-level data on school enrolment are available. These official data were collected by the statistical agency of the Austro-Hungarian Empire for 1900 (no comparable information was collected thereafter until the end of the Austro-Hungarian Empire in 1918). We construct a variable capturing the ratio of the absolute number of compulsory school-aged children to the absolute number of enrolled children. In other words, if this variable is below 1, some of the compulsory school-aged children were not enrolled in school; and if this variable is above 1, some children went to school beyond the age of compulsory schooling. In the sample of all districts, this variable on average equals 1 , but varies between 0.94 and 1.11. Table 4 summarizes the estimation results; a simple linear regression of this ratio on a binary variable equals 1 if this district belonged to the later Soviet zone. Across different specifications (sex- specific, and based on the sample of bordering districts), we find no evidence that school enrolment 
differed between the later occupation zones. Under the assumption that our school enrolment variable captures the pre-WWII educational attainment distribution, we conclude that the internal migrants were not a selected group in terms of human capital.

\subsection{Wartime Destruction and Reconstruction Efforts}

For the interpretation of our empirical estimates below, it is instructive to assess whether the different occupation zones (i) experienced differential wartime destruction and (ii) received differential support in reconstructing the economy in the aftermath of the war.

Wartime Destruction Two measurable dimensions of wartime destruction are lost lives and damage to housing stock. In total, about 370,000 to 380,000 Austrians were killed in WWII. Of these, about two-thirds were military deaths and one-third civilian. Relatively good data exist on military deaths, which allow us to distinguish between soldiers' home towns. Eder (2014) shows that WWII casualties of soldiers were uncorrelated with pre-WWII municipality characteristics and geographic variables. Put differently, there is no evidence for a systematically different mortality rate across occupation zones. Unfortunately, we were unable to find data on civilian deaths by hometown. The best available data source on houses is provided by the Building and Housing Census. The last of these censuses before WWII was conducted in 1934, and the first after WWII in 1951. These census data allow us to reconstruct the housing stock for 1945, details of which are provided in Subsection 5.4. The stock of intact houses in 1945 is a good proxy for wartime destruction, since it is not 'confounded' by any reconstruction efforts. Based on a regression framework (see column I of Table 11), we find no evidence that the number of destroyed houses differed across occupation zones. We conclude that there is no evidence that the wartime destruction differed across occupation zones. ${ }^{12}$

Reconstruction Efforts A rough description of the Soviet occupation in economic terms would be 'exploitative', while the non-Soviet occupation - in particular, that of the US could be described as more 'supportive'. Referring to the Potsdam Agreement, the Soviets claimed 'German assets' (i.e., properties that previously belonged to Germans) within their Austrian occupation zone. Between February and July 1946, the Soviets unilaterally seized 280 industrial enterprises, including the entire Austrian oil industry and the Danube Steam Shipping Company, and a huge area of highly productive agricultural land (Bischof, 2009). By contrast, the Western Allies, especially the US, started to support Austria in 1946, when Austria faced a severe food crisis. National agricultural production of barley contributed

\footnotetext{
${ }^{12}$ In any case, this aspect should play only a minor role in our main estimation analysis. We focus on a sample comprising only municipalities bordering the demarcation line. A discontinuous change in the extent of wartime destruction would not be expected.
} 
half of the food needed to feed the population. In the fall of 1946, the US government started to provide massive amounts of food aid. About 1 year later, the European Recovery Program (ERP), commonly known as the Marshall Plan, was launched. No European country benefited more from the ERP than Austria. ${ }^{13}$ Notably, Austria was the only Soviet-occupied country to join the ERP. From 1947 to 1953, Austria received about USD 1.1 billion without any repayment obligations. ${ }^{14}$ These funds were spent predominantly on projects in the zones of the Western Allies (about 81 percent), and the remainder (about 19 percent) were spent in the Soviet zone (Haas, 2007).

In summary, we conclude that there is no significant evidence of differences in the systematic treatment of Soviet and non-Soviet zones during the war. By contrast, we note that the zones experienced significantly different reconstruction efforts, by which the non-Soviet zone received substantially more foreign support compared to the Soviet zone.

\section{A Simple Spatial Equilibrium Model}

In this section, we employ the spatial equilibrium model of Moretti (2011) to derive predictions of the Allied occupation of Austria on its spatial equilibrium for the period after 1955. The resulting model should inform the interpretation of our empirical results. Our focus is a scenario in which the population is initially equally distributed across two locations. We refer to this situation as a balanced spatial equilibrium (i.e., under identical parameter values, the population is equalized across locations). We then ask the following question: under what circumstances could a temporary shock, such as the Allied occupation, move the economy from its initially balanced spatial equilibrium to an unbalanced spatial equilibrium (i.e., population is unevenly distributed across locations)? It turns out that agglomeration economies and migration frictions are necessary features for the temporary shock to have a permanent effect.

\footnotetext{
${ }^{13}$ The US government provided USD 17 billion (approximately USD 120 billion in current dollar value) of economic support under the framework of the ERP to 17 western and southern European countries. The goals of the US were to rebuild war-devastated regions, remove trade barriers, modernize industry, make Europe prosperous again, gain market platforms in Europe, and prevent the spread of communism.

${ }^{14}$ About 41 percent of these funds were spent immediately on basic foodstuffs, rebuilding infrastructure, such as power plant construction, and reforming the currency. The remaining 59 percent was used for medium- and long-term economic assistance.
} 


\subsection{Model Setup}

\section{Households}

A mass one of workers choose their residences between two locations, conditional on local wages, housing cost, local amenities, and idiosyncratic location preferences. The indirect utility function of a worker $i$ in location $c \in\{a, b\}$ is

$$
U_{i c}=w_{c}-r_{c}+A_{c}+e_{i c}
$$

where $w_{c}$ is the wage rate in location $c, r_{c}$ is the cost of housing, and $A_{c}$ is a measure of local amenities. The term $e_{i c}$ represents idiosyncratic preferences for a certain location and is distributed such that the difference between preferences for two locations is distributed uniformly between $-s$ and $s$ :

$$
e_{i a}-e_{i b} \sim U[-s, s]
$$

The parameter $s$ governs the importance of location preferences for workers.

Households choose their location $c$ to maximize indirect utility. Let $N_{c}$ be the mass of workers who decide to live in location $c{ }^{15}$ The housing stock in each location follows the supply function

$$
r_{c}=z+k N_{c}
$$

where $k$ is the elasticity of supply of housing.

\section{Firms}

Firms in each location use labor and capital to produce a single output good according to a Cobb-Douglas production function

$$
\ln Y_{c}=X_{c}+h N_{c}+(1-h) K_{c}
$$

where $N_{c}$ is the log mass of workers, $K_{c}$ is the log of capital, and $h$ is the labor cost share. The term $X_{c}$ is location-specific log total factor productivity and is determined by agglomeration economies and frictions, such that

$$
X_{c}= \begin{cases}x+\gamma N_{c}, & \text { if } N_{c} \leq N_{d}, c \neq d \\ x+\gamma N_{c}-\delta, & \text { if } N_{c}>N_{d}, c \neq d\end{cases}
$$

\footnotetext{
${ }^{15}$ To be precise, $N_{c}$ is the $\log$ mass of workers in location $c$.
} 
The parameter $\gamma$ governs the strength of linear agglomeration economies. The term $\delta$ represents frictions to population movements, departing from a balanced spatial equilibrium $\left(N_{c}=0.5\right)$. Frictions are modeled as a downward shift in total factor productivity as the population increases. ${ }^{16}$ There are two possible interpretations of this friction term. (i) It captures a reduction of production possibilities, since resources are needed to integrate immigrants (e.g., to increase physical capacities). (ii) Cost of immigration comprises tangible and intangible costs of newly arriving workers. ${ }^{17}$

The price of the output good is normalized to unity. Firms hire labor from the local labor market at wage rate $w_{c}$ and rent capital from the world market at price $q$. All markets are competitive and each firm is small.

Since each single firm is small, it does not take agglomeration economies into account when it hires labor and capital. Hence, the first-order conditions for profit maximization are:

$$
\begin{aligned}
w_{c} & =X_{c}-(1-h) N_{c}+(1-h) K_{c}+\log h \\
q & =X_{c}+h N_{c}-h K_{c}+\log (1-h),
\end{aligned}
$$

where $w_{c}$ is the local wage rate, and $q$ is the world price of capital. Hence, the local wage rate is fully determined by local total factor productivity $X_{c}$, since the combination of equation (6) with equation (5) implies: $w_{c}=\frac{1}{h} X_{c}-\frac{1-h}{h} q+\frac{1-h}{h} \log (1-h)+\log h$.

\subsection{Equilibrium}

Definition 1 An equilibrium in this economy consists of population $N_{c}$, capital stock $K_{c}$, wage rate $w_{c}$, and cost of housing $r_{c}$ for $c \in\{a, b\}$, such that workers choose location $c$ to maximize indirect utility taking prices as given. Firms choose labor and capital input to maximize profit, taking prices as given. In addition, prices are such that labor and housing markets clear.

Definition 2 A stable equilibrium is an equilibrium in which a small mass $\varepsilon$ of workers can change location without creating an incentive for other workers to change location too.

\footnotetext{
${ }^{16}$ Since we are mainly interested in a scenario in which we start from a balanced equilibrium, we keep things simple and introduce frictions only for the expanding location. Furthermore, we assume that first-nature characteristics are equal across locations.

${ }^{17}$ Another way to introduce frictions to migration would be to impose a fixed-utility penalty on workers if they change their locations, that is, $c_{t} \neq c_{t+1}$. This would be more involved mathematically, since a state variable would need to control for the current location of each worker. In that model, there would be two scenarios with possible multiple equilibria: (i) one with strong agglomeration economies as in our preferred model, and (ii) one with large migration costs that outweigh any dispersion forces and hence, no individual would voluntarily move back to their preferred location after a temporary population shock.
} 
A worker $i$ lives in location $b$ if $U_{i b} \geq U_{i a}$. Using the first-order conditions of the firm problem and the indirect utility function, we observe that the utility difference of worker $i$ between locations depends on the relative populations already in place.

$$
\begin{aligned}
U_{i b}-U_{i a} & =\left(w_{b}-w_{a}\right)-\left(r_{b}-r_{a}\right)+\left(A_{b}-A_{a}\right)-\left(e_{i a}-e_{i b}\right) \\
& =\frac{1}{h}\left(X_{b}-X_{a}\right)-k\left(N_{b}-N_{a}\right)-s\left(N_{b}-N_{a}\right) \\
& = \begin{cases}\left(N_{b}-N_{a}\right)\left(\frac{1}{h} \gamma-k-s\right), & \text { if } N_{b}=N_{a} \\
\left(N_{b}-N_{a}\right)\left(\frac{1}{h} \gamma-k-s\right)-\frac{1}{h} \delta, & \text { if } N_{b}>N_{a} .\end{cases}
\end{aligned}
$$

The fixed term for migration frictions generates discontinuity when the population distribution departs from the balanced case. Hence, in any unbalanced equilibrium, the fixed migration frictions need to outweigh higher wages through agglomeration economies. This idea is summarized in the following proposition.

Proposition 1 In the described economy generically, both, a stable balanced and an unbalanced equilibrium exist if and only if (i) agglomeration economies exceed dispersion forces $\left(\frac{1}{h} \gamma>k+s+\frac{1}{h} \delta\right)$ and (ii) there are positive migration frictions $(\delta>0)$.

The proof is provided in Appendix A. The possible equilibrium combinations are summarized in Table 1. Proposition 1 states that multiple stable equilibria exist only in the lower-right panel.

Table 1: Possible Stable Equilibria

\begin{tabular}{c|c|c} 
& $\begin{array}{c}\text { DiSPERSION FORCES EXCEED } \\
\text { AGGLOMERATION ECONOMIES } \\
\left(\frac{1}{h} \gamma<k+s+\frac{1}{h} \delta\right)\end{array}$ & $\begin{array}{c}\text { AGGLOMERATION ECONOMIES } \\
\text { EXCEED DISPERSION FORCES } \\
\left(\frac{1}{h} \gamma>k+s+\frac{1}{h} \delta\right)\end{array}$ \\
\hline $\begin{array}{c}\text { No FRICTIONS } \\
(\delta=0)\end{array}$ & Balanced equ. & Unbalanced equ. \\
\hline $\begin{array}{c}\text { FRICTIONS } \\
(\delta>0)\end{array}$ & Balanced equ. & $\begin{array}{c}\text { Balanced equ. } \\
+\end{array}$ \\
Unbalanced equ.
\end{tabular}

\subsection{Equilibrium Selection}

Proposition 1 states that multiple stable equilibria exist only if there are strong agglomeration economies and frictions to migration. While the total welfare would be higher in an 
unbalanced equilibrium, workers cannot coordinate their location choices to deviate from a balanced equilibrium. An exogenous shock to local amenities causing migration between locations, such as the Allied occupation, could act as a coordination device. If the migration shock is sufficiently large, and hence, generates a wage differential between locations through agglomeration economies that outweigh migration frictions, the economy is pushed to the unbalanced equilibrium. The threshold for the size of the necessary population difference is given by

$$
\left(N_{b}-N_{a}\right)^{\star}=\frac{\delta}{h\left(\frac{1}{h} \gamma-k-s\right)} .
$$

Every population shock that exceeds $\left(N_{b}-N_{a}\right)^{\star}$ pushes the economy to an unbalanced equilibrium.

We conclude from the model that a temporary local amenity shock - the Allied occupation - can push the economy from a stable balanced equilibrium to an unbalanced equilibrium only if the economy features (i) frictions to migration and (ii) agglomeration economies that exceed the dispersion forces (see lower-right panel in Table 1).

\section{Empirical Research Design}

Empirically, the most general question would be as follows. What would the Austrian spatial equilibrium be in the absence of the Allied occupation? However, it seems virtually impossible to construct this entire counterfactual credibly. Our estimation goal is more modest, but nevertheless informative and sufficient to answer our research question. We recognize that both the Soviet and non-Soviet zones have been affected by the Allied occupation and aim to estimate the effect resulting from this differential treatment for the period after 1955, when the demarcation line became completely obsolete.

The Soviet occupation comprises two aspects that distinguish it from the non-Soviet occupation. First and foremost, there is the internal migration response, by which the treatment of the two zones is inversely proportional. The population loss in the Soviet zone is equal to the surplus in the non-Soviet zone. Accordingly, we recognize the Soviet and nonSoviet zones as communicating vessels and aim to estimate the relative effect of the Allied occupation on these two regions. ${ }^{18}$ Second, there is a difference in the economic policy implemented by the different occupying powers. While the Soviet occupation is described as

\footnotetext{
${ }^{18}$ To a small degree, our estimates also reflect the difference in the influx of ethnic German refugees and other displaced people coming to Austria after WWII. As discussed above, the ethnic German refugees were more likely to settle permanently in the non-Soviet zone compared to the Soviet zone. Since this phenomenon was comparably small in absolute terms, it should be of only second-order importance.
} 
more exploitative, the non-Soviet occupation was more supportive. In summary, the differential occupation is the fundamental cause, and the described channels are causal pathways, which cannot be disentangled. Regarding our test of competing hypotheses, it should be emphasized that the differential occupation has not changed any first-nature characteristics.

To achieve this goal we combine two complementary approaches. First, we use pre-WWII data to construct the relative differences between the two regions before treatment. Equivalent to a DiD approach, we assume that the trends in the outcome variables would have been the same for the two regions in the absence of the Allied occupation. ${ }^{19}$ While this assumption is by definition untestable, we can show that this parallel trend assumption holds in the pre-occupation period. Second, we exploit that the demarcation line established a discontinuity in space. We assume that first-nature characteristics do not change discontinuously at the demarcation line. ${ }^{20}$ If this assumption holds true, then a cross-border comparison of municipalities along the demarcation line yields the effect of the differential occupation and the resulting internal migration.

As discussed by Lee and Lemieux (2010), the major concern with discontinuities in space is that they may follow preexisting geographical or political constraints. In our case, preWWII data help to clear any unobserved time-invariant pre-existing differences. Furthermore, the specific location of the demarcation allows us to perform placebo tests that dispel any remaining concerns. The demarcation line coincides in part with pre-exisiting federal state borders and the Danube River. We examine whether we find equivalent treatment effects along federal state borders and along parts of the Danube River, which do not coincide with the demarcation line.

\subsection{Data}

We use municipal-level data on population size, different indicators for economic activity, commuting streams, and the housing stock. These data are drawn from different sources published by Statistik Austria, the Austrian statistical agency, and its predecessor agencies. The vast majority of these data originates from the decennial census. These have been conducted since 1869 with irregular intervals in the inter-war period. ${ }^{21}$ For earlier years,

\footnotetext{
${ }^{19}$ We refrain from referring to our estimation procedure as a DiD approach, since a standard DiD approach assumes that only one group was affect by the treatment.

${ }^{20}$ Clearly, we do not impose the assumption that individuals had no control over which side they would end up in. On the contrary, the internal migration response is precisely the aspect of the Allied occupation we are most interested in. Our identifying assumption refers to the first-nature characteristics.

${ }^{21}$ For 1946 (Österreichisches Statistisches Zentralamt, 1948) and 1948 (Österreichisches Statistisches Zentralamt, 1949), we obtain information on the population from two non-census sources. In 1946, population estimates are based on the number of food stamps. In 1948, population figures are based on an administrative inquiry.
} 
we have to resort to printed publications. For later years (i.e., 1971 and onwards), we have access to electronic individual-level data, which we aggregate at the municipal level ourselves. Population data are available for the full sample period from 1869 to 2011. This long panel dataset allows us to check for any pre-WWII differences across regions. The sectoral composition and housing stock are recorded from 1934 to 2011. Other variables are available only for the post-WWII period. Information on economic activity and commuting streams is available from 1961 to 2011 and from 1961 to 2001, respectively.

Municipal borders have changed significantly since the beginning of our sample period. For instance, the number of municipalities dropped from 4, 397 in 1934 to 2, 354 in 2011. In the case of population data, Statistik Austria provides the adjusted figures after any revision of municipal borders. Thus, we have consistent time series based on current municipal borders. For all other variables, we generate our own time series for the smallest geographic unit we can cleanly trace over time. ${ }^{22}$ In our main estimation sample, which covers the area along the demarcation line (our RDD sample, defined in Subsection 4.2), we end up with 95 mutually exclusive geographic units that comprise 128 municipalities according to the current borders. For simplicity, we refer to these larger geographical units also as municipalities below. Of these municipalities, there are 50 in the former Soviet zone and 45 in the nonSoviet zone.

\subsection{Estimation Samples}

In our analysis, we use different estimation samples, which differ in their geographic coverage. First, we use a sample comprising only municipalities bordering the demarcation line between the Soviet and non-Soviet zone (see Figure 3). ${ }^{23}$ In this sample, we cluster pairs of neighboring municipalities, which are in the Soviet and non-Soviet zones. This sample structure allows us to control for pair-year fixed effects, which should flexibly capture remaining differences in locational fundamentals, such as access to a river or specific topography. The analysis based on this sample - to which we refer as RDD sample below - should exhibit a high degree of internal validity, since pairs of municipalities should not differ except for being in different zones. Since a municipality can have several neighboring municipalities in the other occupation zone, a municipality may enter the sample multiple times as a member of a different pair. Figure 4 depicts one example. Municipality A borders two municipalities (B and $\mathrm{C}$ ) located in the other occupation zone. Thus, municipality A enters the sample

\footnotetext{
${ }^{22}$ If municipalities have merged, we simply aggregate pre-merger data across the merging municipalities. If one municipality has been divided and its parts merged with other municipalities, we aggregate the premerger data across all affected municipalities.

${ }^{23}$ GIS data enable us to identify municipalities that share the occupation zone border, but lie on different sides of it.
} 
twice: once in a pair with municipality B and another time paired with municipality C. Our final RDD sample consists of 93 such municipality pairs.

Table 5 provides descriptive statistics for the primary variables in the overall RDD sample, as well as by occupation zone. All variables are listed in levels; in the estimation analysis, dependent variables enter in logarithmic form. For the outcome variable population, the statistics are provided for each single year. In the case of the remaining outcome variables, only the first and most recent entries are listed.

Second, to examine systematically whether the estimated effects based on this RDD sample reflect only a local phenomenon or a more general pattern, we group municipalities by distance to the demarcation line. The distance groups are defined as follows: 0 to $9 \mathrm{~km}$, 10 to $19 \mathrm{~km}, 20$ to $29 \mathrm{~km}$, and 30 to $39 \mathrm{~km}$. Each municipality is paired up with the closest municipality on the other side of the demarcation line, which belongs to the same distance group. This allows us to estimate the effect, in four different samples, as we move further away from the demarcation line.

Third, as remaining alternatives of sample definitions, we use all municipalities belonging to larger bordering geographical units. These units are, from small to large, court districts, districts, and federal states (Burgenland, Upper Austria, Lower Austria, and Styria). Finally, we use the whole sample of Austrian municipalities. In this set of estimations, we do not pair municipalities.

In either sample definition, we exclude the municipalities of Linz and Steyr. Linz, the capital of the Federal state of Upper Austria, was divided between two occupation zones. The northern part of the city belonged to the Soviet zone, while the southern part belonged to the US zone. Thus, municipal-level data on Linz are aggregated over two different zones. The city of Steyr was exclusively occupied by the US. However, as a result of the aggregation

procedure becoming necessary due to changing municipal borders, as explained above, the municipality of Steyr is nested in a larger geographic unit that spans the demarcation line. Thus, again, we do not have data that allow us to discriminate between the regions in different zones.

\subsection{Estimation Strategy}

Our research design translates into the following estimation model

$$
\begin{aligned}
Y_{i, j, t}= & \alpha^{\prime} \cdot \text { Soviet }_{i, j}+\tau^{\prime} \cdot\left(\text { Soviet }_{i, j} \times \text { Post }_{t}\right)+ \\
& \gamma^{\prime} \cdot\left(\text { Soviet }_{i, j} \times \text { Trend }_{t}\right)+\delta^{\prime} \cdot\left(\text { Soviet }_{i, j} \times \text { Trend }_{t} \times \text { Post }_{t}\right)+ \\
& +\sum_{j, t} \phi_{j, t}^{\prime} \times \text { Municipality-Pair }_{j} \times \text { Year }_{t}+\varepsilon_{i, j, t}^{\prime},
\end{aligned}
$$


where $Y_{i, j, t}$ is the outcome variable of interest in municipality $i$ belonging to the municipality pair $j$ measured in year $t$. The binary variable Soviet $_{i, j}$ is equal to 1 if the municipality belongs to the (former) Soviet zone, and 0 otherwise. The binary variable Post $_{t}$ is equal to 1 for the post-WWII period $(t>1945)$, and Trend $_{t}$ captures a linear time trend. Furthermore, we control for year-specific pair fixed effects $\phi_{j, t}^{\prime}$. The error term is denoted by $\varepsilon_{i, j, t}^{\prime}$. The parameter of primary interest is $\tau^{\prime}$, which can be interpreted as the effect of the Soviet occupation compared to the non-Soviet occupation. A potential drawback of the specification in (11) is that it imposes an immediate and constant effect of the Soviet occupation (this is equivalent to the assumption imposed by a standard DiD approach). To relax this assumption, we consider a further specification,

$$
\begin{aligned}
& Y_{i, j, t}=\alpha^{\prime \prime} \cdot \text { Soviet }_{i, j}+\sum_{t} \tau_{t}^{\prime \prime} \cdot\left(\text { Soviet }_{i, j} \times \text { Year }_{t}\right)+ \\
& \sum_{j, t} \phi_{j, t}^{\prime \prime} \times \text { Municipality-Pair }{ }_{j} \times Y_{\text {ear }}+\varepsilon_{i, j, t}^{\prime \prime},
\end{aligned}
$$

where the $\tau_{t}^{\prime \prime}$ for $t>1945$ (the 'lags') are the effects of interest, and $\tau_{t}^{\prime \prime}$ for $t \leq 1945$ (the 'leads') serve as a falsification test. ${ }^{24}$ The advantage of this specification is that it does not impose any functional-form assumption on the effects of neither lags nor leads, and traces out the full adjustment path of the respective outcome to the Soviet occupation compared to the non-Soviet one.

In the case in which $Y_{i, j, t}$ is equal to the log of the population size, $\tau_{t}^{\prime \prime}$ informs us by what percentage the population in the (former) Soviet zone is different in year $t$ due to the occupation. As stated above, we have to assume that the trends in population size would have been the same in both occupation zones in the absence of the occupation. While this precise assumption is not testable, we can check based on the 'leads' whether the two regions had the same population trend before the occupation.

For some outcome variables, we have not obtained comparable pre-WWII data. In these cases, we estimate a modified specification

$$
\begin{aligned}
Y_{i, j, t}= & \tau_{t}^{\prime \prime \prime} \cdot\left(\text { Soviet }_{i, j} \times \text { Year }_{t}\right)+\sum_{t} \Delta_{t}^{\prime \prime \prime} \cdot \mathbf{X}_{i, 1934 / 39} \times \text { Year }_{t}+ \\
& \sum_{j, t} \phi_{j, t}^{\prime \prime \prime} \times \text { Municipality-Pair } \\
j & \times \text { Year }_{t}+\varepsilon_{i, j, t}^{\prime \prime \prime}, \quad t>1945,
\end{aligned}
$$

where we include a set of covariates measured in pre-WWII periods denoted by $\mathbf{X}_{i, j, 1934 / 39}$.

\footnotetext{
${ }^{24}$ Note, we force $\tau_{t}^{\prime \prime}$ to be 0 in the last year of measurement before WWII to avoid collinearity with the Soviet $_{i, j}$.
} 
This set comprises the log population in 1934 and 1939, the share of males in 1934, and the log of people employed in agriculture and in manufacturing. Here, we have to assume that pre-war trends were similar for these dependent variables and that pre-war differences in levels of the dependent variables can be explained by our control variables.

Throughout the paper, we cluster standard errors at the municipal-pair level $(i, j)$.

\section{$5 \quad$ Estimation Results}

\subsection{Population Size}

Table 6 summarizes the estimation results for the population size based on specification (11). The main finding is a large and statistically significant reduction in the size of the population in the former Soviet zone.

Local effect Column (I) in Panel A is based on our RDD sample, which comprises the municipalities along the demarcation line. The estimate suggests that the population size in the Soviet zone is on average about 11 percent smaller in the post-WWII period compared to the non-Soviet zone. The estimation based on the more flexible specification (12) is depicted in Figure 5. It reveals two important insights. First, the population response is indeed - as imposed by specification (11) - immediate and constant. In 2011, 66 years after the end of WWII, the estimated population drop is more or less the same as in 1946, less than 1 year after the end of the war. Thus, it is innocuous to resort to specification (11). Second, the included leads are neither individually nor jointly statistically significant. This strengthens our confidence that the parallel-trend assumption, which is at the core of our identification strategy, holds. Based on our RDD sample, we conclude that the internal migration shock induced by the Soviet occupation was persistent and shifted the spatial equilibrium.

Generalizability The focus on the municipalities along the demarcation line bears the risk of missing the larger picture. Our estimated effect in column (I) may be only a local phenomenon that is specific to the geographic area along the demarcation line. For instance, people might have left their homes to escape the approaching Soviet army, but did not move far away from their previous homes. Therefore, we examine in the remaining columns of Table 6 the generalizability of this result. It turns out that the population response is quantitatively very comparable, as we move further away from the demarcation line. In columns (II)-(V) of Panel A, we employ estimation samples that are based on municipal pairs that share the same absolute distance to the demarcation line. In this way, we can observe the population drop as we move away from the demarcation line. The estimated 
effects are very comparable with a range from about minus 14 to minus 11 percent. ${ }^{25}$

In columns (VII)-(IX) in Panel B, we include in our sample all municipalities in the bordering court districts, in the bordering districts, and in the bordering federal states, respectively. In these estimations, we do not form municipal-pairs and, thus, do not control for pair-year fixed effects. ${ }^{26}$ Again, we observe quite robust effects. The effects slightly increase as we expand the geographical coverage of our estimation sample. This trend is confirmed by column (X), where we use all Austrian municipalities. Based on this sample, the estimated effect is larger in absolute terms (about minus 19 percent).

This set of results is convincing evidence that the estimated effect in column (I) is not just a local phenomenon. The population drop (rise) in the Soviet (non-Soviet) zone is present throughout. This means that migrants' points of departure (their initial residence) and the points of arrival (their new residence) were equally distributed in space in the respective occupation zone, and, more importantly, this initial distribution was highly persistent over the subsequent 7 decades (see, again, Figure 5).

Placebo tests One threat to our identification strategy is that the occupation zone borders followed the Danube River through Upper Austria and federal state borders, which are natural or pre-existing lines of division. If the area north of the Danube River or certain federal states had different population growth paths after WWII, then the estimated effects might be a spurious correlation that we capture. To rule out this possibility, we run placebo tests that implement hypothetical occupation zone borders. First, we define a placebo demarcation line along the border of the federal states of Lower Austria and Burgenland; both federal states belonged to the Soviet occupation zone. Second, we define a placebo demarcation line along the Danube River in the federal state of Lower Austria, which was located within the former Soviet zone.

Table 7 presents the results of these placebo specifications. Columns (I) and (III) present simple differences in population figures along bordering municipalities, while columns (II) and (IV) include fixed effects for each pair and year of bordering municipalities along the placebo demarcation lines. As expected, in neither of these specifications is there any significant or quantitatively important effect of these placebo occupation zones. These findings support the causal interpretation of our estimation results presented above.

\footnotetext{
${ }^{25}$ In addition, we estimate the effect based on the so-called "doughnut sample." This contains municipal pairs along the demarcation line that are no further apart than $10 \mathrm{~km}$, but do not share a common border. Based on this sample, we estimate a population drop of 11.8 percent, which is statistically indistinguishable from the main result.

${ }^{26}$ For comparison, we replicate the estimation from column (I) without pair-year fixed effects in column (VI). The estimated effect is somewhat larger.
} 


\subsection{Employment and Commuting Behavior}

The previous empirical literature exploiting natural experiments to learn about the determinants of spatial equilibria relies heavily on population data as a proxy for economic activity (see, e.g., Davis and Weinstein, 2002; Bleakley and Lin, 2012; Schumann, 2014). However, population data are a valid proxy for economic activity under only very restrictive assumptions. One has to assume that both the share of the residential population that is economically active and its commuting behavior are evenly distributed in space. We aim to improve upon this literature by analyzing detailed labor-market data from more recent Austrian decennial censuses. Since 1961, we have information on employment at a municipal level. Starting from 1971, we have access to individual-level data. These data include information on individuals' place of residence, employment status, type of employment, place of employment, and time and mode of commuting. We use these data to examine employment, local employment, and commuting streams, in particular, across the former demarcation line. We construct the following municipal-level outcome variables measured in logs:

- Workers : number of residents of municipality $c$ who are employed

- Local workers $s_{c}$ : number of workers who are employed in municipality $c$

- Out-commuters $s_{c}$ number of residents of municipality $c$ who are employed outside of $c$

- In-commuters $s_{c}$ : number of non-residents of municipality $c$ who are employed in $c^{27}$

- Non-commuters ${ }_{c}$ : number of residents of municipality $c$ who are employed in $c$

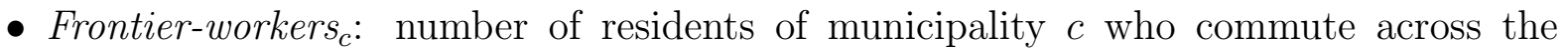
former demarcation line.

Since we do not observe labor-market information in pre-WWII data, we have to adjust our estimation strategy and estimate the model specified in equation (13). Thus, conditional on observable pre-WWII municipality characteristics interacted with year fixed effects and year-specific pair fixed effects, we assume that municipalities belonging to different occupation zones within in our RDD sample are comparable. While this assumption is clearly more restrictive, we can provide evidence in its support based on population data. Column (I) of Table 8 summarizes the estimates for the population response based on equation (13). These estimates are very comparable to those obtained based on the model specified in equation (12), which requires less restrictive assumptions (see Figure 5). We assume the same holds for labor-market data.

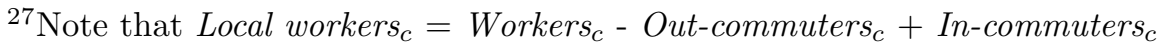


The remaining columns of Table 8 summarize the estimation results for our different labor-market measurements. Column (II) shows that the employed population (workers) dropped by a similar magnitude compared to the resident population (column (I)). Thus, the share of the residential population that is economically active is comparable in the former Soviet and non-Soviet zones. The main result of this section is the large difference in the local workers, as shown in column (III). We estimate a reduction in local employment in the Soviet zone of 13 percent in 1961. This difference is increasing over time in absolute terms, and amounts to minus 28 percent in 2011. Thus, the examination of labor-market outcomes reveals that the economic activity is substantially more concentrated in the former non-Soviet occupation zone compared to the resident population. Put differently, in our case, population data are an invalid proxy for economic activity, since commuting behavior is not uniformly distributed in space.

The remaining columns of Table 8 examine commuting behavior to understand the nature of unequal commuting streams. Columns (IV)-(VI) explore the effect of the shock on the number of out-commuters, in-commuters, and non-commuters. Here, we focus on whether workers cross municipal borders, but not necessarily the former demarcation line. The reductions in out-commuters and non-commuters are of similar magnitude compared to the drop in resident population level. The reduction in in-commuters, however, is substantially more pronounced and amounts to about minus 50 percent in the 1960s and about minus 30 percent in 2011.

In the final column, we examine frontier workers and ask whether more people commute from the former Soviet zone to the former non-Soviet zone compared to the other way round. This estimate is based on a 5 percent random sample of the decennial census from 1971 to 2001. The dependent variable is the share of workers who cross the former demarcation line on their way to work. As expected, we find that substantially more people commute from the former Soviet to the former non-Soviet zone than vice versa. The estimated effect is 15-20 percent.

We conclude that the distribution of economic activity in space is substantially more concentrated as the distribution of the resident population. A further important difference between these two distributions is their dynamic development over time. The drop in the relative population size was persistent, but stayed more or less constant over time (see Figure 5). By contrast, the difference in economic activity, as captured by the local workers, increased over time and almost tripled over a period of about 5 decades. Put differently, if population data were used exclusively as a proxy for economic activity, the degree to which economic activity is unevenly distributed across space would be underestimated. 
As in the case of 'population' outcome, we also estimate the effect of the Allied occupation for our different labor-market outcomes in the four different samples, comprising municipal pairs that are further away from the demarcation line. Table 9 summarizes the estimation output for the outcome of 'local workers'. ${ }^{28}$ We find a very similar pattern across samples, with quite comparable effects. This finding also applies to all other labor-market outcomes. The only notable difference is that the extent of commuting across the former demarcation line decreases somewhat in municipalities that are $30-40 \mathrm{~km}$ away. Detailed estimation output is available in Table B.1 of Appendix B.

\subsection{Sectoral Composition}

In the next step, we analyze whether the Allied occupation affected the spatial distribution of economic activities across sectors. Census data provide us with the number of people working in the agricultural, manufacturing, and services sectors from 1934 to $2011 .^{29}$ As in most industrialized countries, the importance of the agricultural sector decreased sharply over this period in Austria (from 45 percent to 4 percent), while the service sector expanded (from 21 percent to 69 percent). The relative size of the manufacturing sector follows an inverted U-shaped pattern, with a peak in 1971 at 44 percent of total employment. ${ }^{30}$ Since we have pre-WWII data, we can employ the estimation strategy described in equation (12). The respective estimation results for the log share of people working in the agricultural, manufacturing, and services sector are summarized in Table $10 .{ }^{31}$ The mostly insignificant coefficients on the interaction term between the binary variables capturing the data from 1934 and that for the Soviet zone (see first row) indicate that the municipalities along the demarcation line did not differ in their sectoral development before the occupation in agriculture and manufacturing. The significant effect of the services sector trend is economically

\footnotetext{
${ }^{28}$ Note, in this table we cannot control for the full set of covariates, as in Table 8 . We do not have information on the sectoral employment and sex ratio in 1934 for municipalities further away form the demarcation line, since we did not track the development of their municipality borders since 1934. Fortunately, the estimation results in Table 8 change only marginally if we exclude these covariates.

${ }^{29}$ The sectoral shares are calculated based on an employees' municipality of residence. Given that we find stronger employment effects for local workers compared to workers (see Table 8), it would be interesting to define the sectoral shares based on the employer location too. However, this information is not available in the census data before 1971 .

${ }^{30}$ These numbers do not include the city of Vienna.

${ }^{31} \mathrm{Log}$ shares are appropriate in a DiD framework if the common trend of the treatment and control groups changes the sectoral share by a factor, not a constant. Since sectoral shares changed considerably between the base year (1939) and some of the post-war periods, we do not assume that a potential effect on the sectoral share in 1951 remained constant over time, but instead, assume a constant percentage change in the sectoral shares. Therefore, we assume a data-generating process of the form $s_{i, t}=\alpha^{t} \bar{s}_{i} \gamma^{\text {Soviet }_{i}}$, where $\alpha$ is a trend parameter and $\gamma$ is the effect of the Soviet occupation, so that the $\log$ share is $\log s_{i, t}=$ $t \log \alpha+\log \bar{s}_{i}+$ Soviet $_{i} \log \gamma$.
} 
small (plus 0.1 percent), since the services sector accounted for only 12 percent at that time.

The treatment effects are given by the interaction terms using the post-WWII years. We find that initially, it took the Soviet zone longer to shift from agriculture to manufacturing and services. The smaller manufacturing sector remains fairly constant over time, but since the 1970s, the former Soviet zone moved ahead in the services sector. ${ }^{32}$ In summary, we conclude that there has been a distortion in the employment pattern away from manufacturing towards the services sector.

\subsection{Housing Stock}

In the final step, we ask how the occupation affected the spatial equilibrium in terms of houses, and whether the housing stock has fully adjusted to the skewed population distribution. In our model, dispersion forces, such as lower rents in the Soviet zone, may counteract agglomeration effects. Based on the model presented in Glaeser and Gyourko (2005), a certain adjustment process in the housing stock is expected, which might eventually equalize the housing stock per capita across zones. Based on their model, this adjustment process would involve asymmetry, in which housing decline in the Soviet zone is not the mirror image of housing growth in the non-Soviet zone. The simple argument is that houses can be built quickly, but disappear slowly. For this reason, rent prices could vary across zones for an extended period of time. An analysis of the adjustment process of relative housing stock informs us how long dispersion forces exist.

Our housing stock data come from the Building and Housing Census. ${ }^{33}$ Table 11 summarizes our estimation results of the effects of the Soviet occupation on the log of the per capita housing stock. In column (I), the housing stock in 1945 is calculated relative to population before the internal migration response. In column (II), the population after the migration response is used. Apart from this, the two specifications are equivalent. The coefficient on 1945 in column (I) shows, as discussed in Subsection 2.2, that wartime destruction did not differ across occupation zones. The respective coefficient in column (II) shows that in the year(s) 1945/46, right after the migration response, the per capita housing stock in the Soviet zone was 10 percent higher compared to the non-Soviet zone. This closely matches our estimate of the migration response of about 12 percent (see column I of Table 6).

The coefficients on 1951 to 2011 trace out the adjustment process of the per capita housing

\footnotetext{
${ }^{32}$ When the sectoral shares are used as outcome variables, the qualitative picture is very similar, but less pronounced.

${ }^{33}$ This census was conducted in 1934, 1951, 1961, 1971, 1981, 1991, 2001, and 2011. The 1951 census comprises information on the number of destroyed houses in 1951 and the number of rebuilt houses after 1945. Under the assumption that the change in the housing stock from 1934 to 1939 followed the same trend across occupation zones, we can calculate a valid proxy for the housing stock in 1945.
} 
stock over time. Given the nature of our estimation strategy, which provides a relative comparison of the two zones, we are unable to uncover any asymmetry in the adjustment process; we are able to observe only the relative evolution. Until 1951, we observe some adjustment. The housing stock differential decreases to 8 percent. Over the following decades the differential further decreases, but does not vanish. With the exception of 1961, we find a higher housing stock in the Soviet zone of about 4-5 percent. In other words, even after 6 decades, the per capita housing stock is higher in the Soviet zone. This could reflect lower rent prices in the Soviet zone, as our model predicts. However, this dispersion force has not been strong enough to counteract the agglomeration forces sufficiently and to regain population size.

\section{Conclusions}

A long-standing question in economic geography is why economic activity is so highly unevenly distributed across space. While there is broad consensus that densely populated areas offer higher levels of productivity, the source of the productivity gain is less clear. Individuals may cluster in areas that are innately more productive, or density itself may enhance productivity because of agglomeration economies. We provide evidence of the importance of agglomeration effects. In particular, we show that local economies of scale can push — in response to a temporary shock - the economy from one stable balanced spatial equilibrium (i.e., with an even spatial distribution) to a stable unbalanced spatial equilibrium (i.e., with an uneven distribution). Our empirical evidence is based on a population shock induced by the Allied occupation of post-WWII Austria, which lasted from 1945 to 1955. Before tight travel restrictions came into place, about 11 percent of the population residing in the Soviet zone moved across the demarcation line to the occupation zone of the Western Allies. We find that the distorted spatial population distribution has fully persisted until today, 60 years after the demarcation became obsolete. The uneven spatial distribution in economic activity measured by labor-market outcomes has even increased, with large commuting streams out of the former Soviet zone. 


\section{References}

Bischof, G. (2009). Allied Plans and Policies for the Occupation of Austria, 1938-1955. In R. Steininger, G. Bischof and M. Gehle (eds.), Austria in the Twentieth Century, New Brunswick and London: Transaction Publishers, pp. 190-211.

Bleakley, H. and Lin, J. (2012). Portage and Path Dependence. Quarterly Journal of Economics, 127 (2), 587-644.

Bosker, M., Brakman, S., Garretsen, H. and Schramm, M. (2007). Looking for Multiple Equilibria when Geography Matters: German City Growth and the WWII Shock. Journal of Urban Economics, 61 (1), 152-169.

- - - - - and - (2008). A Century of Shocks: The Evolution of the German City Size Distribution 1925-1999. Regional Science and Urban Economics, 38 (4), 330-347.

Brakman, S., Garretsen, H. and Schramm, M. (2004). The Strategic Bombing of German Cities during World War II and its Impact on City Growth. Journal of Economic Geography, 4 (2), 201-218.

Davis, D. R. and Weinstein, D. E. (2002). Bones, Bombs, and Break Points: The Geograohy of Economic Activity. American Economic Review, 92 (5), 1269-1289.

- and - (2008). A Search for Multiple Equilibria in Urban Industrial Structure. Journal of Regional Science, 48 (1), 29-65.

EDER, C. (2014). Missing Men: World War II Casualties and Structural Change. Working Paper No. 1403. The Austrian Center for Labor Economics and the Analysis of the Welfare State.

Eisterer, K. (2009). Austria under Allied Occupation. In R. Steininger, G. Bischof and M. Gehle (eds.), Austria in the Twentieth Century, New Brunswick and London: Transaction Publishers, pp. 190-211.

Eppel, P. (1995). Frauenleben 1945: Kriegsende in Wien; Sonderausstellung des Historischen Museums der Stadt Wien, 21. September - 19. November 1995. Vienna, Austria: Eigenverl. d. Museen d. Stadt Wien.

Erickson, E. L. (1950). The Zoning of Austria. Annales of the American Academy of Political and Social Science, 267, 106-113.

Ferring, R. L. (1968). The Austrian State Treaty of 1955 and the Cold War. Western Political Quarterly, 21 (4), 651-667.

Gabaix, X. (1999). Zipf's Law for Cities: An Explanation. Quarterly Journal of Economics, 114 (3), 739-767.

Glaeser, E. L. and Gyourko, J. (2005). Urban Decline and Durable Housing. Journal of Political Economy, 113 (2), 345-375. 
HaAs, J. (2007). 60 Years of Marshall Plan Aid - A Critical Appraisal from an Austrian Perspective. Monetary Policy $\&$ the Economy, Q2, 126-139.

Head, K. and Mayer, T. (2004). The Empirics of Agglomeration and Trade. In J. V. Henderson and J. Thisse (eds.), Handbook of Regional and Urban Economics, vol. 4, 59, Elsevier, pp. 2609-2669.

Henderson, J. V. (1974). The Types and Size of Cities. American Economic Review, $64(4), 640-656$.

Krugman, P. (1991). Increasing Returns and Economic Geography. Journal of Political Economy, 99 (3), 483-499.

Lee, D. S. and Lemieux, T. (2010). Regression Discontinuity Designs in Economics. Journal of Economic Literature, 48 (2), 281-355.

MAscher-Pichler, H. (2009). Baden bei Wien zur sowjetischen Besatzungszeit 1945-1955 mit besonderer Berücksichtigung der ersten beiden Besatzungsjahre und des Jahres 1955. Ph.D. thesis, University of Vienna, Vienna, Austria.

Miguel, E. and Roland, G. (2011). The Long-run Impact of Bombing Vietnam. Journal of Development Economics, 96 (1), 1-15.

Moretri, E. (2011). Local Labor Markets. In D. Card and O. Ashenfelter (eds.), Handbook of Labor Economics, vol. 4B, 14, Elsevier B.V., pp. 1237-1313.

Ochsner, C. and Roesel, F. (2016). Migrating Extremists. CESIfo Working Paper 5799, Center for Economic Stduies \& Ifo Institute.

Österreichisches Statistisches Zentralamt (1948). Gemeindeverzeichnis von Österreich: Auf Grund einer besonderen Erhebung aus dem Jahre 1946, vol. 1. Wien: Überreuter.

Österreichisches Statistisches Zentralamt (1949). Gemeindeverzeichnis von Österreich, vol. 3. Wien: Überreuter.

Petrov, N. (2009). The Internal Troops of the NKVD in the System of Soviet Organs of Repression in Austria, 1945-1946. In G. Bischof, F. Plasser and B. Stelzl-Marx (eds.), New Perspectives on Austrians and World War II, New Brunswick and London: Transaction Publishers, vol. Contemporary Austrian Stduies, Volume 17.

Radspieler, T. (1955). The Ethnic German Refugee in Austria 1945 to 1955. The Hague, Netherlands: Martinus Nijhoff.

Schumann, A. (2014). Persistence of Population Shocks: Evidence from the Occupation of Wets Germany after World War II. American Econmic Journal: Applied Economics, 6 (3), 189-205.

Stelzl-Marx, B. (2012). Stalins Soldaten in Österreich, vol. 6. München: Böhlau Verlag Wien - Oldenbourg Verlag. 
年

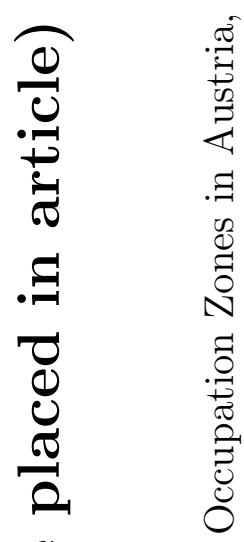

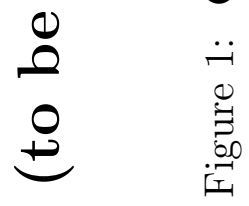

?

๑

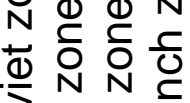

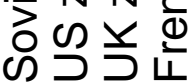

II

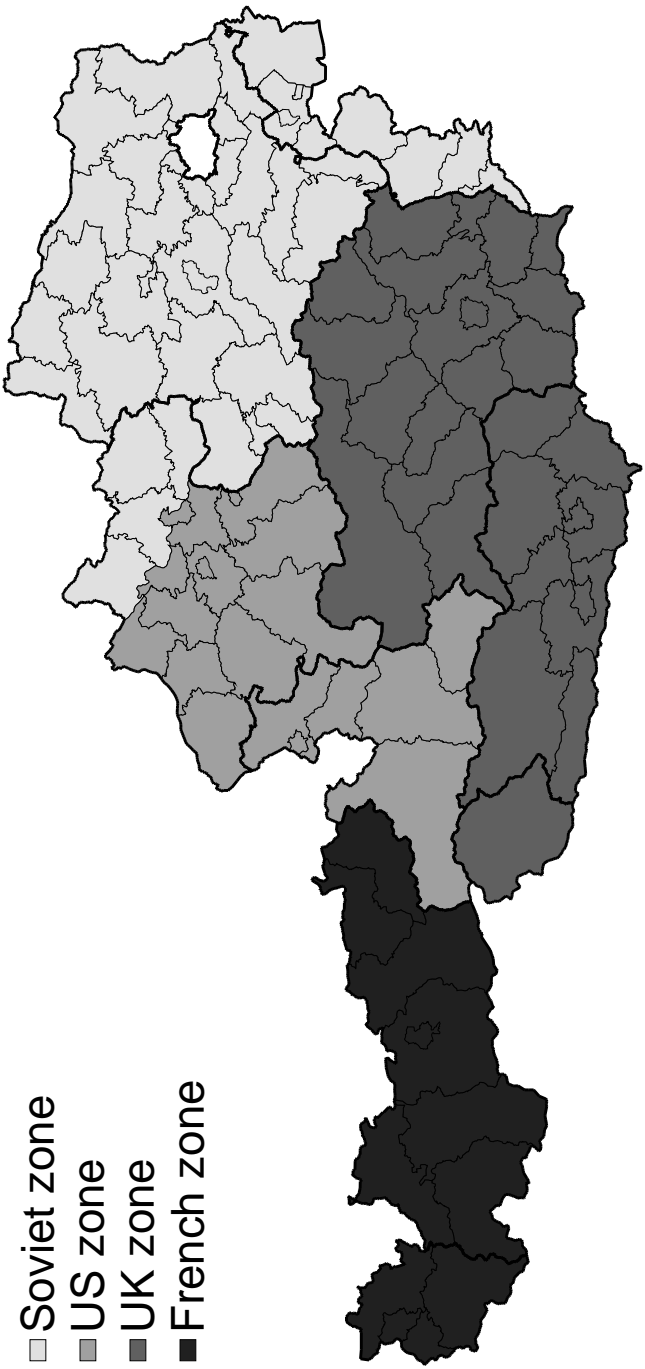

ఠ్ర

$\frac{0}{0}$

$N$ 


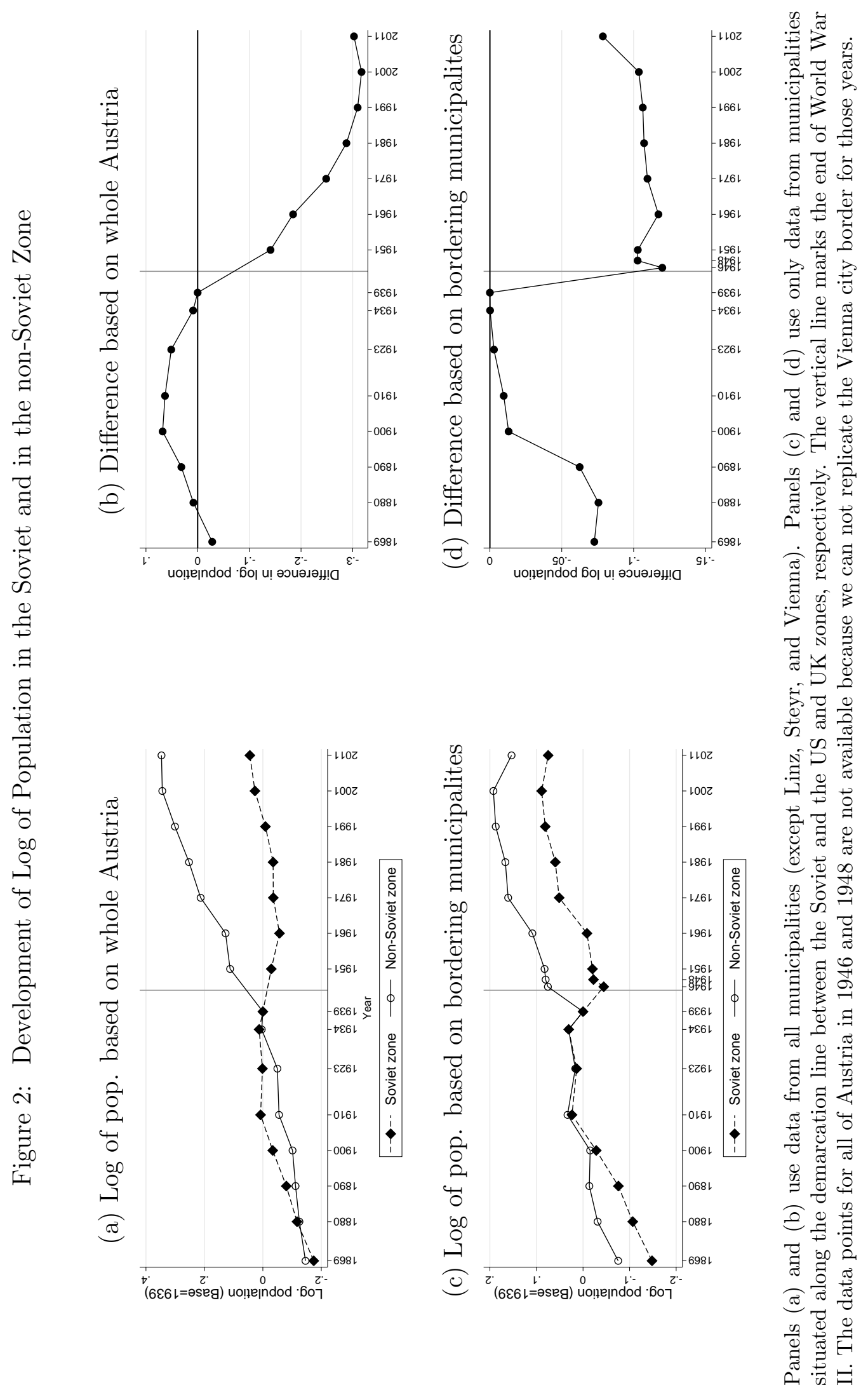




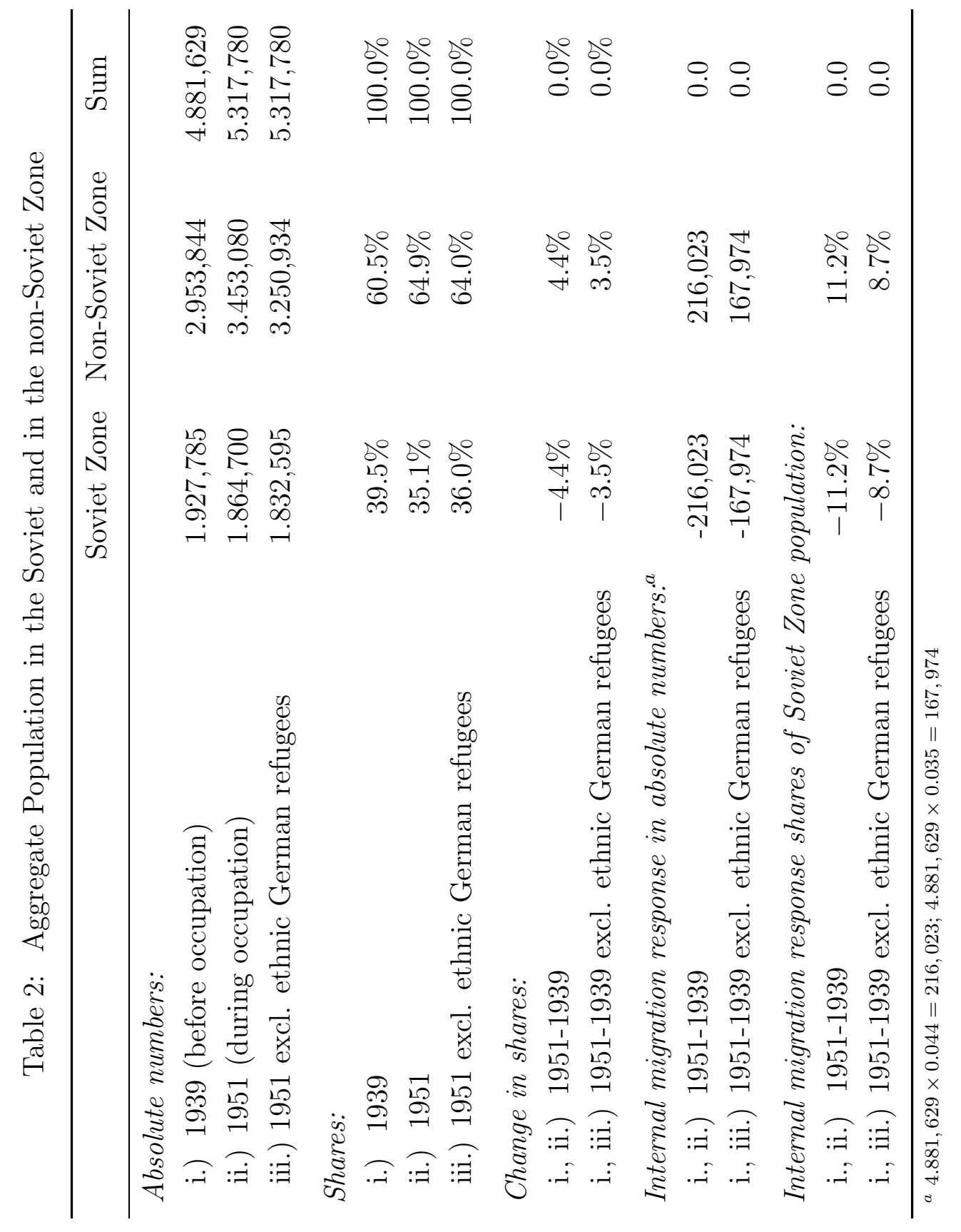


Table 3: Educational Attainment Distribution of Individuals Born before 1920 in the Soviet and in the non-Soviet Zone

\begin{tabular}{lcccc}
\hline & $\begin{array}{c}\text { Tertiary } \\
\text { degree } \\
(\mathrm{III})\end{array}$ & $\begin{array}{c}\text { High school } \\
\text { diploma } \\
(\mathrm{II})\end{array}$ & $\begin{array}{c}\text { Apprentice- } \\
\text { ship } \\
(\mathrm{V})\end{array}$ & $\begin{array}{c}\text { Mandatory } \\
\text { educ. only } \\
(\mathrm{IV})\end{array}$ \\
\hline Soviet zone & 0.010 & 0.016 & 0.123 & 0.826 \\
Non-Soviet zone & 0.010 & 0.019 & 0.128 & 0.818 \\
Difference & -0.000 & -0.002 & -0.004 & 0.008 \\
& $(0.002)$ & $(0.002)$ & $(0.007)$ & $(0.009)$ \\
\hline No. observations & 656 & 656 & 656 & 656 \\
\hline The table lists municipality averages. The sample comprises municipality in \\
the districts along the former demarcation line. Each observation is weighted \\
by the population size to increase efficiency. * ** and *** indicate statistical \\
significance at the 10\% level, 5\% level, and 1\% level, respectively.
\end{tabular}

Table 4: School Enrollment in 1900 in the later Soviet and Non-Soviet Zones

\begin{tabular}{lcccccc}
\hline & All districts in bordering states & \multicolumn{3}{c}{ Bordering districts } \\
& Ratio of enrolled to compulsory school age children \\
& Total & Males & Females & Total & Males & Females \\
& $(\mathrm{I})$ & $(\mathrm{II})$ & $(\mathrm{III})$ & $(\mathrm{IV})$ & $(\mathrm{V})$ & $(\mathrm{VI})$ \\
\hline & & & & & & \\
Soviet zone & -0.003 & 0.006 & -0.014 & -0.008 & -0.001 & -0.015 \\
& $(0.008)$ & $(0.009)$ & $(0.012)$ & $(0.009)$ & $(0.009)$ & $(0.017)$ \\
Border Sample & No & No & No & Yes & Yes & Yes \\
No. observations & 51 & 51 & 51 & 18 & 18 & 18 \\
R-squared & 0.00 & 0.01 & 0.03 & 0.04 & 0.00 & 0.05 \\
Mean of dep. var. & 1.00 & 1.00 & 1.01 & 1.00 & 1.00 & 1.01 \\
S.d. of dep. var. & 0.03 & 0.03 & 0.04 & 0.02 & 0.02 & 0.03 \\
\hline
\end{tabular}

This table summarizes estimation results based on district-level data from 1900. The cities Vienna, Linz and Steyr are excluded, since in all cases the demarcations disunited the city. The border sample consists of districts along the demarcations line. The method of estimation is least squares. Robust standard errors (allowing for clustering by municipality and heteroskedasticity of unknown form) are in parentheses below. ${ }^{*},{ }^{* *}$ and $* * *$ indicate statistical significance at the $10 \%$ level, $5 \%$ level, and $1 \%$ level, respectively. 
Figure 3: Municipalities Included in the RDD-Sample

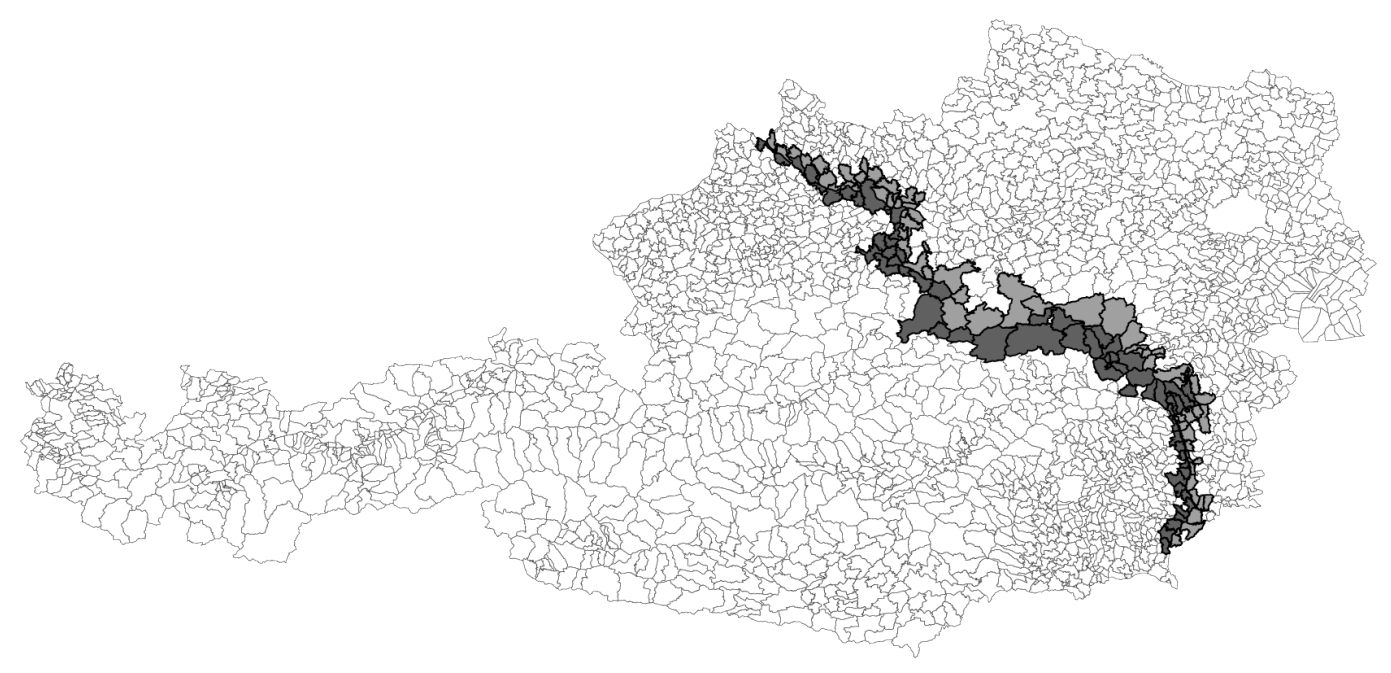

Figure 4: Stylized Example of Bordering Municipality Pairs

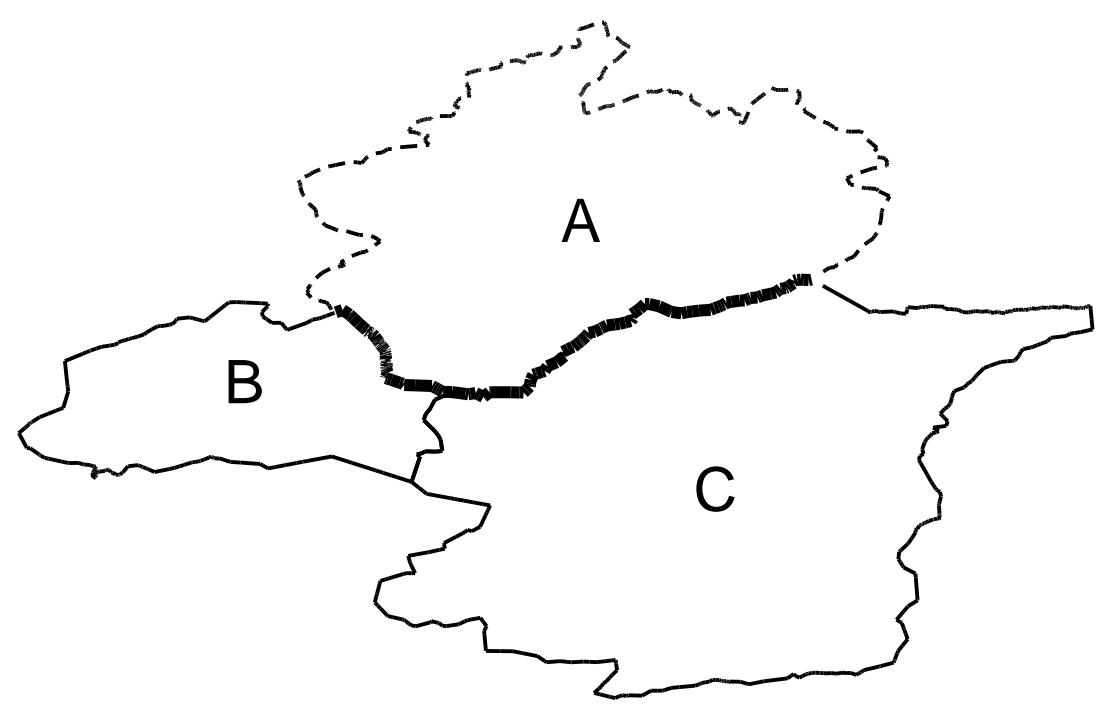

Occupation zone border 
Table 5: Descriptive Statistics for Primary Variables in the RDD-Sample

\begin{tabular}{|c|c|c|c|c|c|}
\hline & \multicolumn{3}{|c|}{ Both Zones } & \multirow{2}{*}{$\begin{array}{c}\text { Non-Soviet Zone } \\
\text { Mean }\end{array}$} & \multirow{2}{*}{$\begin{array}{l}\text { Soviet Zone } \\
\text { Mean }\end{array}$} \\
\hline & Obs. & Mean & Std. Dev. & & \\
\hline \multicolumn{6}{|l|}{ Outcome variables } \\
\hline \multicolumn{6}{|l|}{ Population } \\
\hline in 1869 & 95 & $1,988.1$ & $1,513.9$ & $1,885.7$ & $2,080.4$ \\
\hline in 1880 & 95 & $2,079.2$ & $1,627.8$ & $1,973.5$ & $2,174.3$ \\
\hline in 1890 & 95 & $2,160.5$ & $1,809.6$ & $2,073.8$ & $2,238.5$ \\
\hline in 1900 & 95 & $2,217.6$ & $1,953.5$ & $2,106.4$ & $2,317.7$ \\
\hline in 1910 & 95 & $2,348.5$ & $2,182.9$ & $2,259.6$ & $2,428.4$ \\
\hline in 1923 & 95 & $2,345.8$ & $2,323.0$ & $2,290.6$ & $2,395.4$ \\
\hline in 1934 & 95 & $2,382.0$ & $2,344.5$ & $2,318.6$ & $2,439.1$ \\
\hline in 1939 & 95 & $2,322.5$ & $2,306.1$ & $2,257.3$ & $2,381.2$ \\
\hline in 1946 & 95 & $2,405.9$ & $2,498.9$ & $2,496.5$ & $2,324.3$ \\
\hline in 1948 & 95 & $2,432.1$ & $2,536.5$ & $2,498.0$ & $2,372.8$ \\
\hline in 1951 & 95 & $2,428.2$ & $2,532.3$ & $2,494.2$ & $2,368.9$ \\
\hline in 1961 & 95 & $2,510.9$ & $2,720.4$ & $2,618.6$ & $2,413.9$ \\
\hline in 1971 & 95 & $2,684.2$ & $2,936.8$ & $2,800.4$ & $2,579.7$ \\
\hline in 1981 & 95 & $2,759.8$ & $3,135.1$ & $2,897.4$ & $2,635.9$ \\
\hline in 1991 & 95 & $2,853.1$ & $3,267.8$ & $2,998.9$ & $2,721.8$ \\
\hline in 2001 & 95 & $2,924.9$ & $3,387.9$ & $3,054.1$ & $2,808.7$ \\
\hline in 2011 & 95 & $2,938.5$ & $3,612.1$ & $3,079.3$ & $2,811.7$ \\
\hline \multicolumn{6}{|l|}{ Workers } \\
\hline in 1961 & 95 & $1,142.7$ & $1,154.3$ & $1,174.5$ & $1,114.0$ \\
\hline in 2011 & 95 & $1,425.9$ & $1,742.8$ & $1,477.9$ & $1,379.1$ \\
\hline \multicolumn{6}{|l|}{ Local workers } \\
\hline in 1961 & 95 & 994.7 & $1,118.9$ & $1,040.4$ & 953.6 \\
\hline in 2011 & 95 & $1,045.6$ & $1,710.8$ & $1,185.7$ & 919.5 \\
\hline \multicolumn{6}{|l|}{ Share of frontier workers } \\
\hline in 1971 & 95 & 0.121 & 0.172 & 0.048 & 0.186 \\
\hline in 2001 & 95 & 0.203 & 0.216 & 0.106 & 0.291 \\
\hline \multicolumn{6}{|l|}{ Share in agriculture } \\
\hline in 1934 & 95 & 0.512 & 0.197 & 0.526 & 0.501 \\
\hline in 2011 & 95 & 0.073 & 0.058 & 0.078 & 0.068 \\
\hline \multicolumn{6}{|l|}{ Share in manufacturing } \\
\hline in 1934 & 95 & 0.224 & 0.106 & 0.209 & 0.237 \\
\hline in 2011 & 95 & 0.311 & 0.057 & 0.312 & 0.310 \\
\hline \multicolumn{6}{|l|}{ Share in services } \\
\hline in 1934 & 95 & 0.118 & 0.094 & 0.112 & 0.124 \\
\hline in 2011 & 95 & 0.617 & 0.075 & 0.610 & 0.623 \\
\hline \multicolumn{6}{|l|}{ Control Variables } \\
\hline Population in 1934 & 95 & $2,382.0$ & $2,344.5$ & $2,318.6$ & $2,439.1$ \\
\hline Population in 1939 & 95 & $2,322.5$ & $2,306.1$ & $2,257.3$ & $2,381.2$ \\
\hline Population in agriculture in 1934 & 95 & $1,048.0$ & 702.8 & 965.1 & $1,122.6$ \\
\hline Population in manufacturing in 1934 & 95 & 609.3 & 875.0 & 576.8 & 638.6 \\
\hline Share of male population in 1934 & 95 & 0.497 & 0.016 & 0.495 & 0.499 \\
\hline
\end{tabular}


Table 6: Estimation of the Effect of the Soviet Occupation on the Log of Population

\begin{tabular}{|c|c|c|c|c|c|}
\hline Panel A: & $\begin{array}{c}\text { Bordering } \\
\text { municipalities } \\
\text { (I) }\end{array}$ & $\begin{array}{l}\text { Municipalities } \\
0-10 \mathrm{~km} \\
\text { (II) }\end{array}$ & $\begin{array}{l}\text { s with distance } \\
10-20 \mathrm{~km} \\
\text { (III) }\end{array}$ & $\begin{array}{c}\text { e to the demarce } \\
20-30 \mathrm{~km} \\
\text { (IV) }\end{array}$ & $\begin{array}{c}\text { ation line of } \\
30-40 \mathrm{~km} \\
\text { (V) }\end{array}$ \\
\hline Soviet zone $\times$ Post WWII & $\begin{array}{c}-0.118^{* * *} \\
(0.016)\end{array}$ & $\begin{array}{c}-0.137^{* * *} \\
(0.018)\end{array}$ & $\begin{array}{c}-0.108^{* * *} \\
(0.014)\end{array}$ & $\begin{array}{c}-0.129^{* * *} \\
(0.011)\end{array}$ & $\begin{array}{c}-0.115^{* * *} \\
(0.013)\end{array}$ \\
\hline Soviet zone & $\begin{array}{c}0.119 \\
(0.116)\end{array}$ & $\begin{array}{c}-0.055 \\
(0.072)\end{array}$ & $\begin{array}{c}0.064 \\
(0.069)\end{array}$ & $\begin{array}{c}0.034 \\
(0.064)\end{array}$ & $\begin{array}{c}0.003 \\
(0.055)\end{array}$ \\
\hline Trend $\times$ Soviet zone & $\begin{array}{c}0.000 \\
(0.001)\end{array}$ & $\begin{array}{c}-0.000 \\
(0.000)\end{array}$ & $\begin{array}{c}-0.001^{* *} \\
(0.000)\end{array}$ & $\begin{array}{c}-0.001^{* * *} \\
(0.000)\end{array}$ & $\begin{array}{c}0.000 \\
(0.000)\end{array}$ \\
\hline Trend $\times$ Soviet zone $\times$ Post WWII & $\begin{array}{r}-0.000 \\
(0.001)\end{array}$ & $\begin{array}{r}-0.000 \\
(0.001)\end{array}$ & $\begin{array}{c}0.000 \\
(0.001)\end{array}$ & $\begin{array}{c}-0.001 \\
(0.001)\end{array}$ & $\begin{array}{c}-0.002^{* * *} \\
(0.001)\end{array}$ \\
\hline Pair-Year FE & Yes & Yes & Yes & Yes & Yes \\
\hline No. pairs & 93 & 128 & 228 & 210 & 194 \\
\hline No. unique municipal. & 95 & 157 & 244 & 218 & 199 \\
\hline No. periods & 17 & 15 & 15 & 15 & 15 \\
\hline No. observations & 3,162 & 3,840 & 6,840 & 6,300 & 5,820 \\
\hline R-squared & 0.48 & 0.63 & 0.53 & 0.54 & 0.58 \\
\hline Mean of dep. var. & 7.64 & 7.26 & 7.22 & 7.20 & 7.16 \\
\hline S.d. of dep. var. & 0.77 & 0.66 & 0.75 & 0.66 & 0.65 \\
\hline Panel B: & $\begin{array}{c}\text { Bordering } \\
\text { municipalities } \\
\text { (VI) }\end{array}$ & $\begin{array}{c}\text { Bordering } \\
\text { court districs } \\
(\mathrm{VII})\end{array}$ & $\begin{array}{c}\text { Bordering } \\
\text { districts } \\
\text { (VIII) }\end{array}$ & $\begin{array}{c}\text { Bordering } \\
\text { states } \\
\text { (IX) }\end{array}$ & $\begin{array}{l}\text { All of } \\
\text { Austria } \\
\text { (X) }\end{array}$ \\
\hline Soviet zone $\times$ Post WWII & $\begin{array}{c}-0.155^{* * *} \\
(0.035)\end{array}$ & $\begin{array}{c}-0.115^{* * *} \\
(0.012)\end{array}$ & $\begin{array}{c}-0.113^{* * *} \\
(0.011)\end{array}$ & $\begin{array}{c}-0.152^{* * *} \\
(0.007)\end{array}$ & $\begin{array}{c}-0.189^{* * *} \\
(0.006)\end{array}$ \\
\hline Soviet zone & $\begin{array}{c}0.136 \\
(0.142)\end{array}$ & $\begin{array}{l}0.158^{* * *} \\
(0.058)\end{array}$ & $\begin{array}{l}0.172^{* * *} \\
(0.055)\end{array}$ & $\begin{array}{l}0.338^{* * *} \\
(0.035)\end{array}$ & $\begin{array}{l}0.425^{* * *} \\
(0.033)\end{array}$ \\
\hline Trend $\times$ Soviet zone & $\begin{array}{c}0.001 \\
(0.001)\end{array}$ & $\begin{array}{r}-0.000 \\
(0.000)\end{array}$ & $\begin{array}{r}-0.000 \\
(0.000)\end{array}$ & $\begin{array}{l}0.001^{* * *} \\
(0.000)\end{array}$ & $\begin{array}{c}0.000 \\
(0.000)\end{array}$ \\
\hline Trend $\times$ Soviet zone $\times$ Post WWII & $\begin{array}{c}-0.001 \\
(0.002)\end{array}$ & $\begin{array}{c}0.000 \\
(0.001)\end{array}$ & $\begin{array}{c}0.000 \\
(0.001)\end{array}$ & $\begin{array}{c}-0.001^{* * *} \\
(0.000)\end{array}$ & $\begin{array}{c}-0.003^{* * *} \\
(0.000)\end{array}$ \\
\hline Year FE & Yes & Yes & Yes & Yes & Yes \\
\hline No. unique municipal. & 90 & 561 & 622 & 1,725 & 2,351 \\
\hline No. periods & 15 & 15 & 15 & 15 & 15 \\
\hline No. observations & 1,350 & 8,415 & 9,330 & 25,875 & 35,265 \\
\hline R-squared & 0.01 & 0.02 & 0.02 & 0.04 & 0.06 \\
\hline Mean of dep. var. & 7.30 & 7.16 & 7.14 & 7.25 & 7.20 \\
\hline S.d. of dep. var. & 0.71 & 0.70 & 0.70 & 0.75 & 0.83 \\
\hline
\end{tabular}

This table summarizes estimation results based on municipality-level data from 1869, 1880, 1890, 1900, 1910, 1923, 1934, 1939, 1946, 1948, 1951, 1961, 1971, 1981, 1991, 2001, 2011. The cities Linz, Steyr, and Vienna are excluded, since in both cases the demarcations disunited the city. The dependent variable is equal to the log of population. Each specification includes the variables listed. Specifications (I)-(V) controls in addition for pair-wise year fixed effects (where pairs are given by neighboring municipalities along the demarcations line). The method of estimation is least squares. Robust standard errors (allowing for clustering by municipality and heteroskedasticity of unknown form) are in parentheses below. *, ** and *** indicate statistical significance at the $10 \%$ level, $5 \%$ level, and $1 \%$ level, respectively. 


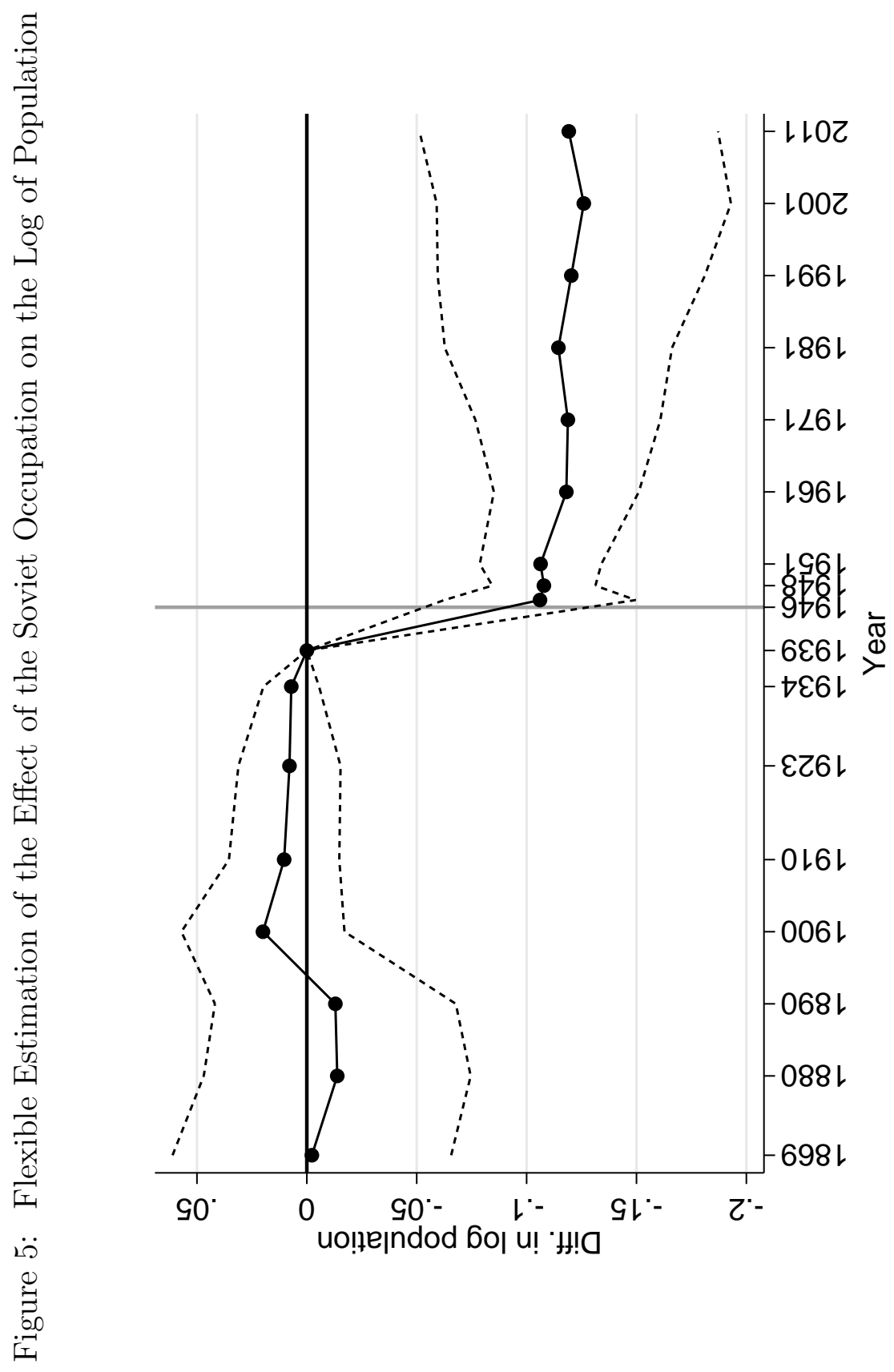


Table 7: The Effect of Placebo Demarcation Lines on the Log of Population

\begin{tabular}{lcccc}
\hline & \multicolumn{4}{c}{ Placebo demarcation line } \\
& along state border & \multicolumn{2}{c}{$\begin{array}{c}\text { along Danube river } \\
\text { within Soviet zone }\end{array}$} \\
& $(\mathrm{I})$ & $(\mathrm{II})$ & $(\mathrm{III})$ & $(\mathrm{IV})$ \\
\hline & 0.006 & -0.011 & -0.021 & 0.004 \\
Placebo zone $\times$ Post WWII & $(0.033)$ & $(0.021)$ & $(0.041)$ & $(0.024)$ \\
& -0.181 & 0.010 & -0.513 & $-0.992^{* * *}$ \\
Placebo zone & $(0.208)$ & $(0.099)$ & $(0.310)$ & $(0.216)$ \\
& 0.000 & $0.001^{*}$ & -0.001 & $-0.002^{* *}$ \\
Trend $\times$ Placebo zone & $(0.001)$ & $(0.001)$ & $(0.001)$ & $(0.001)$ \\
& -0.001 & -0.002 & 0.002 & $0.003^{* *}$ \\
Trend $\times$ Placebo zone $\times$ Post WWII & $(0.001)$ & $(0.001)$ & $(0.002)$ & $(0.001)$ \\
Pair-year FE & No & $Y$ es & No & $Y$ es \\
No. pairs & $\cdot$ & 56 &. & 34 \\
No. unique municipal. & 56 & 56 & 41 & 41 \\
No. periods & 15 & 15 & 15 & 15 \\
No. observations & 840 & 1,680 & 615 & 1,020 \\
R-squared & 0.03 & 0.62 & 0.09 & 0.72 \\
Mean of dep. var. & 7.40 & 7.41 & 7.51 & 7.76 \\
S.d. of dep. var. & 0.70 & 0.61 & 0.87 & 1.09 \\
\hline
\end{tabular}

This table summarizes estimation results based on municipality-level data from 1869, 1880, 1890, 1900, 1910, 1923, 1934, 1939, 1951, 1961, 1971, 1981, 1991, 2001, 2011. The dependent variable is equal to the log of population. Each specification includes the variables listed and pair-wise year fixed effects (where pairs are given by neighboring municipalities along the placebo occupation zone border). The method of estimation is least squares. Robust standard errors (allowing for clustering by municipality and heteroskedasticity of unknown form) are in parentheses below. *, ${ }^{* *}$ and ${ }^{* * *}$ indicate statistical significance at the $10 \%$ level, $5 \%$ level, and $1 \%$ level, respectively. 


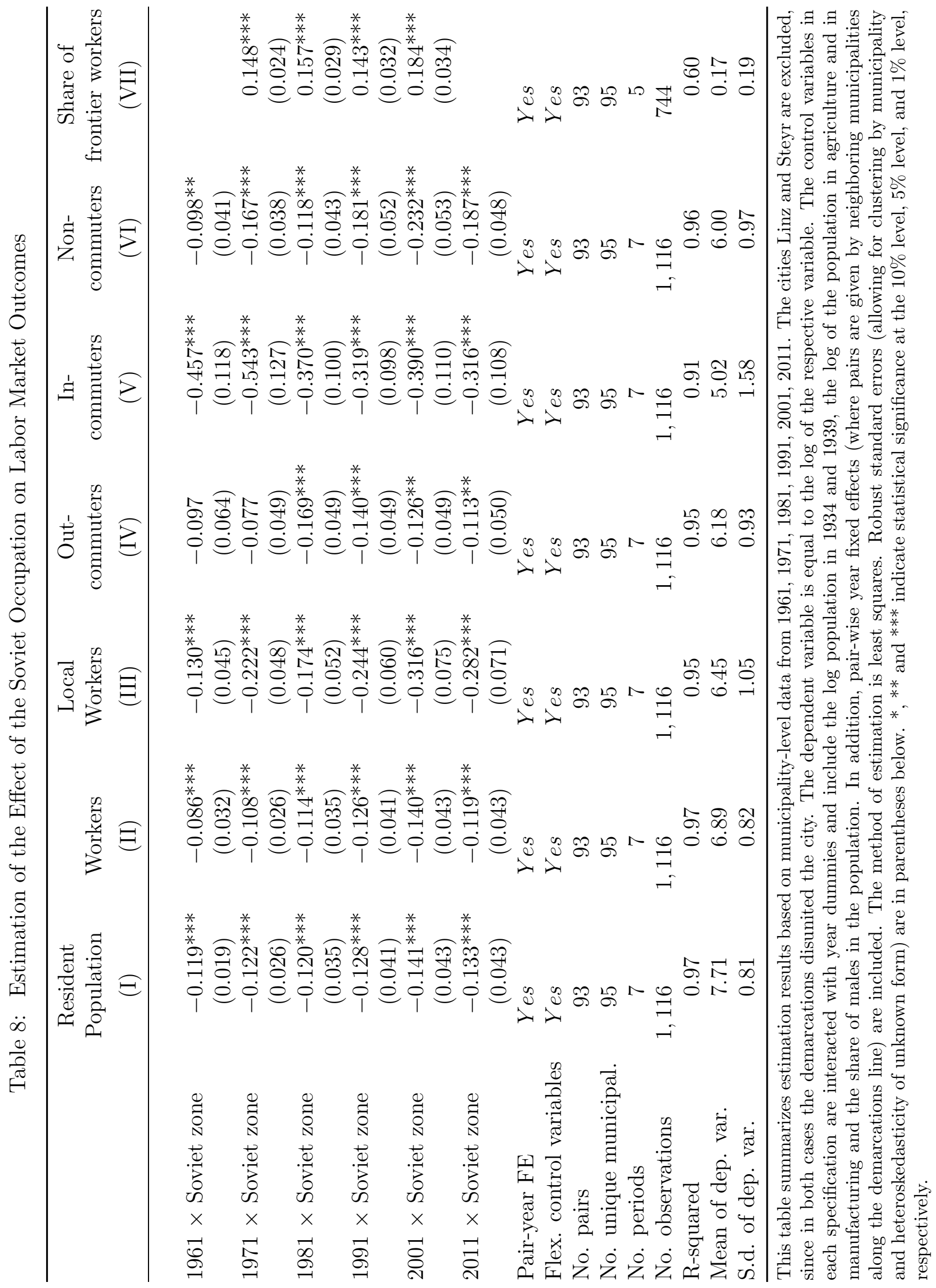


Table 9: Estimation of the Effect of the Soviet Occupation on Labor Market Outcomes: Robustness Checks

\begin{tabular}{|c|c|c|c|c|}
\hline & $\begin{array}{l}\text { Municipalities } \\
0-10 \mathrm{~km} \\
\text { (I) }\end{array}$ & $\begin{array}{l}\text { Local W } \\
\text { s with distance } \\
10-20 \mathrm{~km} \\
\text { (II) }\end{array}$ & $\begin{array}{l}\text { orkers } \\
\text { to the demarca } \\
20-30 \mathrm{~km} \\
\text { (III) }\end{array}$ & $\begin{array}{l}\text { tion line of } \\
30-40 \mathrm{~km} \\
\text { (IV) }\end{array}$ \\
\hline $1961 \times$ Soviet zone & $\begin{array}{c}-0.169^{* *} \\
(0.067)\end{array}$ & $\begin{array}{c}-0.117^{* * *} \\
(0.038)\end{array}$ & $\begin{array}{r}-0.051 \\
(0.039)\end{array}$ & $\begin{array}{c}-0.072^{* *} \\
(0.031)\end{array}$ \\
\hline $1971 \times$ Soviet zone & $\begin{array}{c}-0.238^{* * *} \\
(0.060)\end{array}$ & $\begin{array}{c}-0.167^{* * *} \\
(0.046)\end{array}$ & $\begin{array}{c}-0.218^{* * *} \\
(0.047)\end{array}$ & $\begin{array}{c}-0.064 \\
(0.040)\end{array}$ \\
\hline $1981 \times$ Soviet zone & $\begin{array}{c}-0.192^{* * *} \\
(0.072)\end{array}$ & $\begin{array}{c}-0.168^{* * *} \\
(0.057)\end{array}$ & $\begin{array}{c}-0.281^{* * *} \\
(0.052)\end{array}$ & $\begin{array}{c}-0.090^{* *} \\
(0.045)\end{array}$ \\
\hline $1991 \times$ Soviet zone & $\begin{array}{c}-0.280^{* * *} \\
(0.081)\end{array}$ & $\begin{array}{c}-0.284^{* * *} \\
(0.065)\end{array}$ & $\begin{array}{c}-0.338^{* * *} \\
(0.057)\end{array}$ & $\begin{array}{r}-0.096^{*} \\
(0.057)\end{array}$ \\
\hline $2001 \times$ Soviet zone & $\begin{array}{c}-0.345^{* * *} \\
(0.099)\end{array}$ & $\begin{array}{c}-0.217^{* * *} \\
(0.065)\end{array}$ & $\begin{array}{c}-0.433^{* * *} \\
(0.061)\end{array}$ & $\begin{array}{l}-0.201^{* * *} \\
(0.066)\end{array}$ \\
\hline $2011 \times$ Soviet zone & $\begin{array}{c}-0.335^{* * *} \\
(0.091)\end{array}$ & $\begin{array}{c}-0.247^{* * *} \\
(0.071)\end{array}$ & $\begin{array}{c}-0.486^{* * *} \\
(0.063)\end{array}$ & $\begin{array}{c}-0.255^{* * *} \\
(0.072)\end{array}$ \\
\hline Pair-Year FE & Yes & Yes & Yes & Yes \\
\hline No. pairs & 88 & 180 & 170 & 137 \\
\hline No. unique municipal. & 115 & 199 & 179 & 141 \\
\hline No. periods & 6 & 6 & 6 & 6 \\
\hline No. observations & 1,056 & 2,160 & 2,040 & 1,644 \\
\hline R-squared & 0.87 & 0.89 & 0.86 & 0.89 \\
\hline Mean of dep. var. & 6.28 & 6.01 & 5.98 & 6.15 \\
\hline S.d. of dep. var. & 1.01 & 1.19 & 0.97 & 0.93 \\
\hline
\end{tabular}

This table summarizes estimation results based on municipality-level data from 1961, 1971, 1981, 1991, 2001, 2011. The cities Linz and Steyr are excluded, since in both cases the demarcations disunited the city. The control variables in each specification are interacted with year dummies and include the log population in 1934 and 1939 (additional pre-war control variables would reduce the sample size considerably). In addition, pair-wise year fixed effects (where pairs are given by neighboring municipalities along the demarcations line) are included. The method of estimation is least squares. Robust standard errors (allowing for clustering by municipality and heteroskedasticity of unknown form) are in parentheses below. ${ }^{*},{ }^{* *}$ and ${ }^{* * *}$ indicate statistical significance at the $10 \%$ level, $5 \%$ level, and $1 \%$ level, respectively. 
Table 10: Estimation of the Effect of the Soviet Occupation on the Sectoral Composition

\begin{tabular}{|c|c|c|c|}
\hline & $\begin{array}{c}\text { Log of } \\
\text { share in } \\
\text { agriculture } \\
\text { (I) }\end{array}$ & $\begin{array}{c}\text { Log of } \\
\text { share in } \\
\text { manufacturing } \\
\text { (II) }\end{array}$ & $\begin{array}{l}\text { Log of } \\
\text { share in } \\
\text { services } \\
\text { (III) }\end{array}$ \\
\hline $1934 \times$ Soviet zone & $\begin{array}{c}0.003 \\
(0.026)\end{array}$ & $\begin{array}{r}-0.032 \\
(0.027)\end{array}$ & $\begin{array}{l}0.105^{* *} \\
(0.052)\end{array}$ \\
\hline Soviet zone $($ Base $=1939)$ & $\begin{array}{c}0.037 \\
(0.068)\end{array}$ & $\begin{array}{l}0.150^{* * *} \\
(0.052)\end{array}$ & $\begin{array}{c}-0.218^{* *} \\
(0.086)\end{array}$ \\
\hline $1951 \times$ Soviet zone & $\begin{array}{c}0.047^{*} \\
(0.027)\end{array}$ & $\begin{array}{c}-0.114^{* * *} \\
(0.029)\end{array}$ & $\begin{array}{c}0.061 \\
(0.057)\end{array}$ \\
\hline $1961 \times$ Soviet zone & $\begin{array}{c}0.069^{*} \\
(0.038)\end{array}$ & $\begin{array}{c}-0.114^{* * *} \\
(0.025)\end{array}$ & $\begin{array}{c}0.096 \\
(0.059)\end{array}$ \\
\hline $1971 \times$ Soviet zone & $\begin{array}{c}0.052 \\
(0.055)\end{array}$ & $\begin{array}{c}-0.101^{* *} \\
(0.040)\end{array}$ & $\begin{array}{c}0.109^{*} \\
(0.065)\end{array}$ \\
\hline $1981 \times$ Soviet zone & $\begin{array}{c}-0.032 \\
(0.060)\end{array}$ & $\begin{array}{c}-0.085^{*} \\
(0.045)\end{array}$ & $\begin{array}{l}0.144^{* *} \\
(0.072)\end{array}$ \\
\hline $1991 \times$ Soviet zone & $\begin{array}{r}-0.092 \\
(0.065)\end{array}$ & $\begin{array}{c}-0.110^{* *} \\
(0.051)\end{array}$ & $\begin{array}{l}0.183^{* *} \\
(0.080)\end{array}$ \\
\hline $2001 \times$ Soviet zone & $\begin{array}{c}-0.179 * * \\
(0.076)\end{array}$ & $\begin{array}{c}-0.149^{* * *} \\
(0.056)\end{array}$ & $\begin{array}{l}0.226^{* * *} \\
(0.082)\end{array}$ \\
\hline $2011 \times$ Soviet zone & $\begin{array}{c}-0.106 \\
(0.077)\end{array}$ & $\begin{array}{c}-0.162^{* * *} \\
(0.050)\end{array}$ & $\begin{array}{l}0.228^{* * *} \\
(0.083)\end{array}$ \\
\hline Pair-Year FE & Yes & Yes & Yes \\
\hline No. pairs & 93 & 93 & 93 \\
\hline No. unique municipal. & 95 & 95 & 95 \\
\hline No. periods & 9 & 9 & 9 \\
\hline No. observations & 1,674 & 1,674 & 1,674 \\
\hline R-squared & 0.87 & 0.81 & 0.92 \\
\hline Mean of dep. var. & -1.69 & -1.12 & -1.48 \\
\hline S.d. of dep. var. & 1.15 & 0.43 & 0.91 \\
\hline
\end{tabular}

This table summarizes estimation results based on municipality-level data from 1934, 1939, 1951, 1961, 1971, 1981, 1991, 2001, 2011. The cities Linz and Steyr are excluded, since in both cases the demarcations disunited the city. In addition, pair-wise year fixed effects (where pairs are given by neighboring municipalities along the demarcations line) are included. The method of estimation is least squares. Robust standard errors (allowing for clustering by municipality and heteroskedasticity of unknown form) are in parentheses below. ${ }^{*}, * *$ and $* * *$ indicate statistical significance at the $10 \%$ level, $5 \%$ level, and $1 \%$ level, respectively. 
Table 11: Estimation of the Effect of the Soviet Occupation on the Evolution of the Housing Stock

\section{Log housing stock per capita}

$\begin{array}{lc}\text { Soviet Zone }(\text { Base }=1934) & 0.054^{*} \\ & (0.023) \\ 1945 \times \text { Soviet zone } & \\ \text { (Population of } 1934 \text { as base) } & -0.014 \\ & (0.013)\end{array}$

$1945 \times$ Soviet zone

(Population of 1946 as base)

$1951 \times$ Soviet zone

$1961 \times$ Soviet zone

$1971 \times$ Soviet zone

$1981 \times$ Soviet zone

$1991 \times$ Soviet zone

$2001 \times$ Soviet zone

$2011 \times$ Soviet zone

Pair-Year FE

No. pairs

No. unique municipal.

No. periods

No. observations

R-squared

Mean of dep. var.

S.d. of dep. var.
(I)

(0.013)

$$
0.054^{* *}
$$

This table summarizes estimation results based on municipality-level data for the housing stock per capita in 1934, 1945, 1951, 1961, 1971, 1981, 1991, 2001, 2011. The dependent variable is equal to the $\log$ of the number of houses per capita. Column (I) uses houses in 1945 divided by the population of 1934 as the dependent variable in 1945, while column (II) uses houses in 1945 divided by the population of 1946. Each specification includes the variables listed and pair-wise year fixed effects (where pairs are given by neighboring municipalities along the placebo occupation zone border). The method of estimation is least squares. Robust standard errors (allowing for clustering by municipality and heteroskedasticity of unknown form) are in parentheses below. *, ** and *** indicate statistical significance at the $10 \%$ level, $5 \%$ level, and $1 \%$ level, respectively. 


\section{Appendix A: Proof of Proposition 1}

Proof 1 The proof consists of five steps. First, we show that under the above described parameter combination a stable balanced equilibrium (Step 1) and an unbalanced equilibrium exist (Step 2). In Step 3, we show that if agglomeration economies are weak, there is no unbalanced equilibrium. In Step 4 we show that if there are strong agglomeration economies but no migration frictions, the balanced equilibrium is not stable. Finally, in Step 5 we show that in another parameter combination there are also a stable balanced and an unbalanced equilibria, but that parameter combination has a mass of zero.

Steps 1 and 2 ensure that conditions (i) and (ii) in Proposition 1 are sufficient and Steps 3 and 4 show that these conditions are necessary.

Without loss of generality, in an unbalanced allocation of workers we always consider $N_{b}>N_{a}$.

Note that the idiosyncratic location preference term $e_{i a}-e_{i b}$ in equation (7) ensures that if worker $i$ is indifferent between locations, then worker $j$ with $e_{j a}-e_{j b}>e_{i a}-e_{i b}$ prefers to live in location $a$, while every worker $l$ with $e_{l a}-e_{l b}<e_{i a}-e_{i b}$ prefers location $b$.

Step 1

Let $\frac{1}{h} \gamma>k+s+\frac{1}{h} \delta$ (strong agglomeration economies) and $\delta>0$ (migration frictions exist). When both locations have an equal mass of workers, i.e. $N_{b}=0.5$, then every worker with $e_{i a}-e_{i b}>0$ lives in location $a$, every worker with $e_{i a}-e_{i b}<0$ lives in location $b$, while the worker with $e_{i a}-e_{i b}=0$ is indifferent between locations. Hence, no worker has an incentive to change location and therefore the balanced equilibrium exists.

If a mass of $\varepsilon>0$ of workers moves to location $b$, then the worker with the highest preference for location $b$ in the set $\varepsilon$ would experience a utility difference between locations of

$$
U_{i b}-U_{i a}=2 \varepsilon\left(\frac{1}{h} \gamma-k\right)-\frac{1}{h} \delta .
$$

For $\varepsilon$ sufficiently small, $U_{i b}-U_{i a}<0$ and that worker prefers location a. Since all other workers in the set $\varepsilon$ have a higher location preference for a, they prefer location a as well. Hence, a small deviation from the balanced equilibrium does not change the preferred location of any worker and therefore the balanced equilibrium is stable.

Step 2

In the situation with strong agglomeration economies $\left(\frac{1}{h} \gamma>k+s+\frac{1}{h} \delta\right)$ and migration frictions $(\delta>0)$, the allocation $N_{b}=1$ is an equilibrium. The utility difference for the worker with the least preference for location $b$ is

$$
U_{i b}-U_{i a}=\left(\frac{1}{h} \gamma-k-s\right)-\frac{1}{h} \delta
$$

which is positive under the assumed parameter combination.

Step 3

Now assume weak agglomeration economies $\left(\frac{1}{h} \gamma<k+s+\frac{1}{h} \delta\right)$. If any mass $\varepsilon>0$ of workers 
move to location $b$, the worker with the strongest preference for location a in that set would prefer location a to location $b$. The utility difference for that worker is

$$
U_{i b}-U_{i a}=2 \varepsilon\left(\frac{1}{h} \gamma-k-s\right)-\frac{1}{h} \delta
$$

Since $\frac{1}{h} \gamma<k+s+\frac{1}{h} \delta$ by assumption, the term is always negative for $\varepsilon \in[0,0.5]$ and the worker with the strongest preference for location a in the set $\varepsilon$ would never stay in location $b$.

Because this argument is true for any $\varepsilon \in[0,0.5]$, there is no unbalanced equilibrium.

Step 4

In the case with strong agglomeration economies $\left(\frac{1}{h} \gamma>k+s\right)$ but not migration frictions $(\delta=0)$, then the balanced equilibrium is not stable. Consider a small mass $\varepsilon>0$ of workers who change location from a to $b$. The utility difference of the worker in that set with the least preference for location $b$ is

$$
\begin{aligned}
U_{i b}-U_{i a} & =2 \varepsilon\left(\frac{1}{h} \gamma-k-s\right)-\frac{1}{h} \delta \\
& =2 \varepsilon\left(\frac{1}{h} \gamma-k-s\right),
\end{aligned}
$$

because $\delta=0$. This term is always positive and hence a small perturbation to the equal distribution of workers towards location b would cause ever more workers to prefer location $b$ to location a. Hence, the balanced equilibrium is not stable.

\section{Step 5}

Let there be agglomeration economies that exactly offset dispersion forces $\left(\frac{1}{h} \gamma=k+s\right)$ and there are no migration frictions $(\delta=0)$. In that situation, any for mass $\varepsilon>0$ that moves from location a to $b$, the worker with the least preference for location $b$ experiences a utility difference of

$$
U_{i b}-U_{i a}=2 \varepsilon\left(\frac{1}{h} \gamma-k-s\right)
$$

which is zero by assumption. Hence, each worker in that set would be indifferent between locations $a$ and $b$.

However, the parameter combination $\frac{1}{h} \gamma=k+s$, i.e. production parameters exactly equal the sum of a parameter from the housing market and a preference parameter is an event with zero mass and this is therefore not a generic case.

\section{Summary}

Taken together, in these four steps we show that there is only one group of parameter combinations that lead to multiple stable equilibria, out of which one has an equal distribution of workers between locations. In all other parameter combinations either the unbalanced equilibrium does not exist or the balanced equilibrium is not stable.

Q.E.D. 


\section{Appendix B: Additional Estimation Output}

Table B.1: Estimation of the Effect of the Soviet Occupation on Frontier Workers: Robustness Checks

\begin{tabular}{|c|c|c|c|c|}
\hline & $\begin{array}{l}\text { Municipalities } \\
\text { 0-10 km } \\
\text { (I) }\end{array}$ & $\begin{array}{l}\text { Share of fron } \\
\text { with distance } \\
10-20 \mathrm{~km} \\
\text { (II) }\end{array}$ & $\begin{array}{l}\text { ier workers } \\
\text { to the demarca } \\
20-30 \mathrm{~km} \\
\text { (III) }\end{array}$ & $\begin{array}{l}\text { tion line of } \\
30-40 \mathrm{~km} \\
\text { (IV) }\end{array}$ \\
\hline $1971 \times$ Soviet zone & $\begin{array}{l}0.195^{* * *} \\
(0.019)\end{array}$ & $\begin{array}{l}0.091^{* * *} \\
(0.010)\end{array}$ & $\begin{array}{l}0.067^{* * *} \\
(0.010)\end{array}$ & $\begin{array}{l}0.040^{* * *} \\
(0.005)\end{array}$ \\
\hline $1981 \times$ Soviet zone & $\begin{array}{l}0.208^{* * *} \\
(0.026)\end{array}$ & $\begin{array}{l}0.104^{* * *} \\
(0.015)\end{array}$ & $\begin{array}{l}0.123^{* * *} \\
(0.013)\end{array}$ & $\begin{array}{l}0.071^{* * *} \\
(0.009)\end{array}$ \\
\hline $1991 \times$ Soviet zone & $\begin{array}{l}0.219^{* * *} \\
(0.027)\end{array}$ & $\begin{array}{l}0.129^{* * *} \\
(0.015)\end{array}$ & $\begin{array}{l}0.108^{* * *} \\
(0.013)\end{array}$ & $\begin{array}{l}0.094^{* * *} \\
(0.011)\end{array}$ \\
\hline $2001 \times$ Soviet zone & $\begin{array}{l}0.271^{* * *} \\
(0.028)\end{array}$ & $\begin{array}{l}0.165^{* * *} \\
(0.016)\end{array}$ & $\begin{array}{l}0.129^{* * *} \\
(0.013)\end{array}$ & $\begin{array}{l}0.102^{* * *} \\
(0.013)\end{array}$ \\
\hline Pair-year FE & Yes & Yes & Yes & Yes \\
\hline Flex. control variables & Yes & Yes & Yes & Yes \\
\hline No. pairs & 912 & 912 & 912 & 912 \\
\hline No. unique municipal. & 971 & 971 & 971 & 971 \\
\hline No. periods & 4 & & & \\
\hline No. observations & 1,044 & 1,827 & 1,675 & 1,560 \\
\hline R-squared & 0.56 & 0.57 & 0.63 & 0.60 \\
\hline Mean of dep. var. & 0.20 & 0.11 & 0.08 & 0.05 \\
\hline S.d. of dep. var. & 0.21 & 0.16 & 0.14 & 0.11 \\
\hline
\end{tabular}

This table summarizes estimation results based on municipality-level data from 1971, 1981, 1991, 2001. The cities Linz and Steyr are excluded, since in both cases the demarcations disunited the city. The control variables in each specification are interacted with year dummies and include the log population in 1934 and 1939 (additional pre-war control variables would reduce the sample size considerably). In addition, pair-wise year fixed effects (where pairs are given by neighboring municipalities along the demarcations line) are included. The method of estimation is least squares. Robust standard errors (allowing for clustering by municipality and heteroskedasticity of unknown form) are in parentheses below. ${ }^{*}, * *$ and $* * *$ indicate statistical significance at the $10 \%$ level, $5 \%$ level, and $1 \%$ level, respectively. 